\title{
Occurrence Mechanism of Roof-Fall Accidents in Large-Section Coal Seam Roadways and Related Support Design for Bayangaole Coal Mine, China
}

\author{
Shitan Gu, ${ }^{1,2}$ Bangyou Jiang $\mathbb{D}^{1,2}$ Gensheng Wang, ${ }^{3}$ Huabin Dai, ${ }^{1}$ and Mingpeng Zhang ${ }^{3}$ \\ ${ }^{1}$ State Key Laboratory of Mining Disaster Prevention and Control Co-Founded by Shandong Province and the Ministry of Science \\ and Technology, Shandong University of Science and Technology, Qingdao 266590, China \\ ${ }^{2}$ National Demonstration Center for Experimental Mining Engineering Education, Shandong University of Science and \\ Technology, Qingdao 266590, China \\ ${ }^{3}$ Bayangaole Coal Mine, Shandong Energy Zibo Mining Group Co., Ltd., Ordos 017300, China
}

Correspondence should be addressed to Bangyou Jiang; jiangbangyou123@163.com

Received 18 April 2018; Accepted 10 June 2018; Published 11 July 2018

Academic Editor: Mohsen S. Masoudian

Copyright (c) 2018 Shitan Gu et al. This is an open access article distributed under the Creative Commons Attribution License, which permits unrestricted use, distribution, and reproduction in any medium, provided the original work is properly cited.

\begin{abstract}
This study focused on large-scale roof-fall accidents occurred in large-section coal seam roadways of Bayangaole Coal Mine, Inner Mongolia, China, and investigated the occurrence mechanism of roof-fall and the related supporting control method in detail. Firstly, the fracture characteristics of the surrounding rocks on the roadway roof were measured using a stratum detector. The results showed that the roadway roof underwent the most severe failure with a maximum deformation of $3.53 \mathrm{~m}$; the bedding separation and fracture zones were distributed at irregular intervals. Accordingly, the entire stratum was separated into several thin sublayers, significantly reducing the stability of roof. In addition, the roof medium grained sandstone of roadway is water-rich strata, and water aggravates the damage of roof. Next, the mechanism of the occurrence of roof-fall accidents in the roadway was elucidated in detail. The following three reasons are mainly attributed to the occurrence of roof-fall accidents: (i) effects of mininginduced stress and tectonic stress, (ii) existence of equipment cavern on the side of roadway, and (iii) unreasonable support parameters. On that basis, a new supporting design is proposed, including a more reasonable arrangement of anchor cables and bolts, bolts with full-length anchorage which are applicable in cracked and water-rich roadway, high-strength anchor cables, and crisscrossed steel bands. Moreover, high pretightening force was applied. Finally, a field test was performed, and the mininginduced roof displacement and stress on anchor cable (bolt) were monitored in the test section. The maximum roof displacements at the two monitoring sections were $143 \mathrm{~mm}$ and $204 \mathrm{~mm}$, respectively, far smaller than the roadway's allowable deformation. Moreover, the stress on roof anchor cables (bolts) was normal, and no anchorage-dragging and tensile failure phenomena were observed. The monitoring data indicated that the new supporting design was remarkable on the control of large-section coal seam roadway roof deformation.
\end{abstract}

\section{Introduction}

With the improvement of modern comprehensive mechanization technology as well as the popularization and application of some high-yielding and high-efficiency coal mining techniques such as top-coal caving mining and fullseam mining, large-scale and fast-advancing intensive mining mode has now become an important development direction in China's coal mining; moreover, the use of large- scale equipment in the work face, a significant increase in mining intensity and yield, and the enhancement of transportation capability in mines have set higher requirements for the section size of roadway [1]. However, the increasing roadway section caused many problems in the support and control of surrounding rocks in roadway. According to the investigation results, under intensive mining-induced disturbance, both sides of a large-section coal seam roadway showed great deformation, and floor 
heaving, severe roof settling, and even roof-fall accidents occurred, severely hindering the safe and efficient mining of coal [2-6]. In recent years, China's mining focus has gradually shifted to the western regions. The mines in Western China significantly differ from those in Eastern China in terms of geological conditions and roof lithology. For these mines in Western China, the roof rocks above the coal seam are mainly composed of sandy mudstone with a large thickness, complex variation, and poor interlaminar cementing performance, and the roofs of the excavated large-section roadways usually lack safety, easily leading to large-scale roof-fall accidents and severe security risks $[7,8]$. Therefore, it is of great significance to investigate roof-fall mechanisms in large-section coal seam roadways and related supporting countermeasures and solve the problems of roof support and control in large-section coal seam roadways under high-intensity mining to guarantee high efficiency and safe production in mines.

Currently, a great deal of research has been performed on the mechanisms, prediction, and support control of rooffall accidents in coal roadways. Some scholars systematically analyzed the causes of roof-fall accidents in mines and pointed out that roof-fall accidents in underground mines were mainly caused by many factors including geological conditions, crustal stress state, water, the arrangement in mines, and mine environment [9-18]. Roof-fall accidents in mine roadways were also caused by these factors. Du et al. [19] concluded the cause of roadway roof-fall accidents and proposed GSM-based classification methods; accordingly, roof-fall accidents in roadways can be divided into the following three types: (i) G-type roof-fall accidents related to natural geological factors, (ii) S-type roof-fall accidents related to support, and (iii) M-type roof-fall accidents related to technical factors in mining. Moreover, the occurrence mechanism of each type of roof-fall accidents was analyzed in detail. Jia [20] first made the statistics of hundreds of roof-fall accidents in coal roadways supported by anchor bolts and found that the main reason was the combination of inferior stratum degradation. Jacobi [21] found that the roof separation in vertical direction was the main reason that led to severe roof settling or even fall in roadways; this can also be regarded as a sign of rock-fall accidents. Further, Tan et al. [22] analyzed the mechanism of roof separation and indicated that vertical bedding separation velocity ratio can be used to predict the occurrence of roof separation in roadways and evaluate the safety of roof support. Jiang et al. [23] concluded that the development of joint fissures in a stratum and the lack of targeted supports were the main reasons that caused a large deformation and instability of roadway roofs.

In previous studies, researchers analyzed the mechanisms of roof-fall accidents in coal roadways, investigated the related influencing factors from different perspectives, and obtained a lot of important results. However, based on a thorough knowledge of roadway roof-fall mechanism, more targeted supporting control measures should be further used for different types of roof-fall accidents to more effectively avoid the occurrence of accidents. He and Zhang [24] found that large-section intensive mining can affect the failure characteristics of roadway roofs, and the use of combined support of truss cable and grouting reinforcement achieved the safe control of large-section coal seam roadway roofs. Yan et al. [25] established second tunneling and the control system for multisupport structures in extra-largesection roadways and achieved favorable roof control performances. Li et al. [26] first analyzed the roof-fall mechanisms of roadways with a mudstone roof and then established the surrounding rock control system for different roofs and regions and proposed the coupled control technology including high-quality bolt, prestressed anchor cable, and grouting reinforcement. For addressing the falling accidents of mudstone roofs in roadways when touching water, Yao et al. [27] proposed a roof control technique by combining drilling dewatering, grouting water retention, and high-strength prestressed anchor bolt (cable). Meng et al. $[28,29]$ proposed a three-anchor combined supporting system consisting of an anchor bolt, an anchor cable, and grouting; the internal grouting bolt was used as the core. However, because of different geological conditions, technical mining conditions, and supporting patterns, the rooffall mechanisms were also different in different roadways. Therefore, different supporting measures should be used, and the parameters should be set more pertinently, requiring a great deal of focused research.

This study focused on Bayangaole Mine located in Erdos, a city in Western China. First, the fracture characteristics of the surrounding roadway rocks were evaluated using the borehole peering technique; then, large-section coal seam roadway roof-fall mechanisms were elucidated in combination with a roof mechanical model. Based on the evaluation on original supports and parameters, a novel supporting scheme and related parameter setting are proposed. Finally, using this novel support system, field tests were conducted. According to the field monitoring results, this novel support system achieved favorable controlling performance on roof settling in a large-section coal seam roadway.

\section{Geological Conditions and Engineering Background}

2.1. Geological Conditions. Bayangaole Coal Mine is located in the southern part of Erdos, the Nei Mongol autonomous region, China, and at the northeastern edge of Maowusu Desert. As shown in Figure 1, this region has a plateau semidesert landform. The designed production capacity of this mine is $4.0 \mathrm{Mt} / \mathrm{a}$. Number 3-1 coal seam was the first choice for mining. Geological drilling results show that both the immediate roof and floor of this coal seam were composed of sandy mudstone with average thicknesses of $5.97 \mathrm{~m}$ and $7.40 \mathrm{~m}$, respectively. The coal seam has a burial depth of approximately $600 \mathrm{~m}$, an average thickness of $5.58 \mathrm{~m}$, and an inclination angle of $1-3^{\circ}$. Figure 2 shows the detailed lithologic characteristics of the coal seam. And the roof medium grained sandstone is water-rich strata; roof water can weaken the anchorage ability of anchor cable (bolt) seriously. 


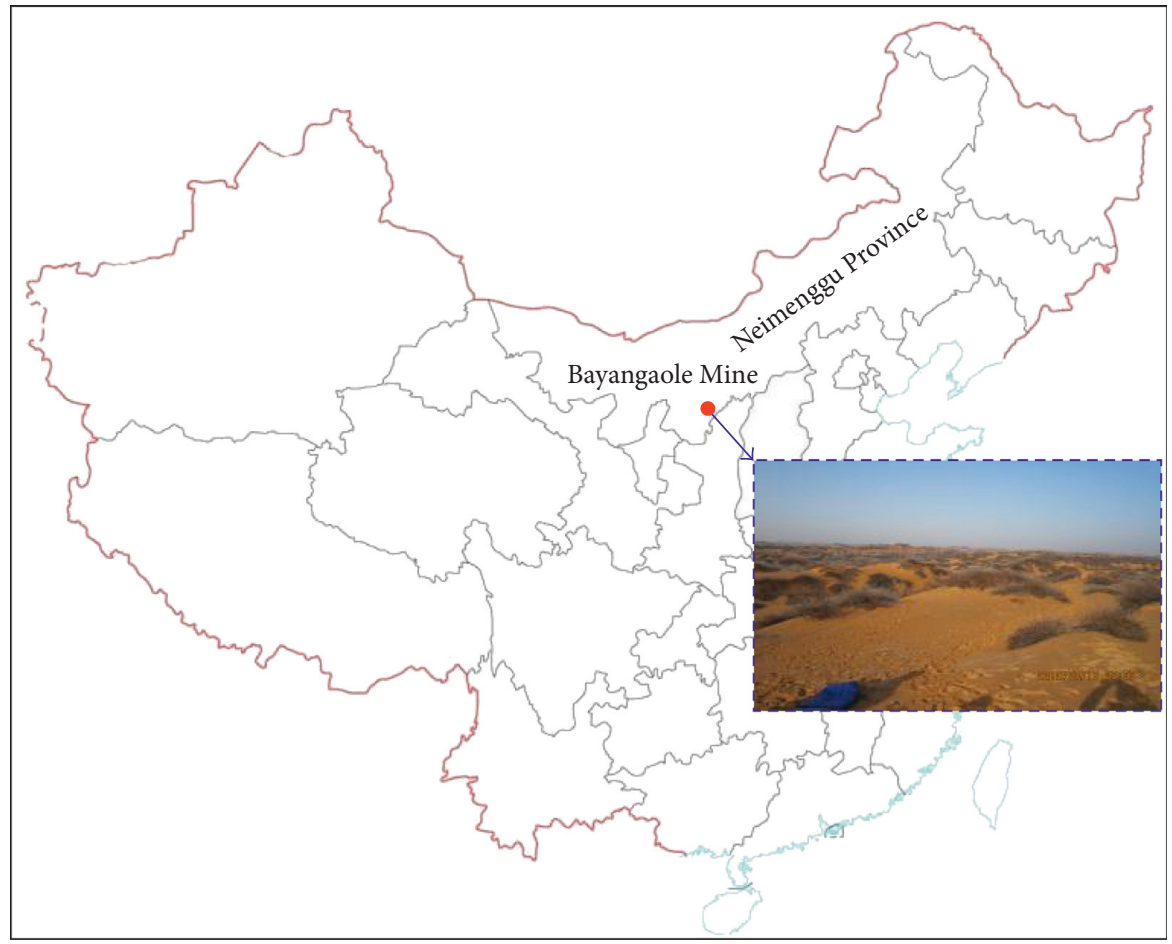

FIgURE 1: Geographic position and surface landform of Bayangaole coal mine.

2.2. Engineering Background. Numbers 311101 and 311102 working faces are the first two working faces in number 11 panel of Bayangaole coal mine. Figure 3 shows the arrangement in these two working faces; WJ03 and WJ08 are the drilling positions in geological detection. In these two working faces, long-wall full-seam mining with complete mechanization was used for coal cutting. The mining roadway was advanced along the floor of the coal seam, and the roadway section was a rectangular section with a width of $5.4 \mathrm{~m}$ and a height of $4.2 \mathrm{~m}$. As shown in Figure 4, both anchor network and cables were used for support. The spacing (along the direction perpendicular to the roadway's axial direction) and array pitch (along the roadway's axial direction) of anchor bolts were both $1.0 \mathrm{~m}$, while the spacing and array pitch between the anchor cables were $1.6 \mathrm{~m}$ and $3.0 \mathrm{~m}$. Both the bolts and cables were anchored on both the sides using a resin anchoring agent.

At about 8:00, April 23, 2015, when number 311102 working face was advanced to $210 \mathrm{~m}$, the anchor cables in ventilation roadway were fractured, and roof stratum 51$62 \mathrm{~m}$ in front of the working face fell (i.e., the position filled with red grid lines shown in Figure 3 ). The roadway where the roof fell had a length of approximately $12 \mathrm{~m}$, the maximum fall height of the roof was almost $5.0 \mathrm{~m}$, and the section of the roadway with the fall height over $1.5 \mathrm{~m}$ was approximately $6 \mathrm{~m}$ in length. At about 0:44, April 24, 2015, when number 311101 working face was advanced to $50 \mathrm{~m}$ away from the withdraw roadway, the anchor cables in the main belt conveyor roadway were fractured, and the roof strata 5-21 $\mathrm{m}$ in front of the withdraw roadway fell (i.e., the position filled with red graticule lines shown in Figure 3). The roadway where the roof fell was approximately $16 \mathrm{~m}$ in length, the maximum fall height also exceeded $5.0 \mathrm{~m}$, and the section of the roadway with the fall height over $1.5 \mathrm{~m}$ was approximately $9.0 \mathrm{~m}$ in length. The fallen rocks pressed the belt conveyor, thus stopping the production in the working face. As also shown in Figure 3, two equipment caverns with a width of $5.0 \mathrm{~m}$, a height of $3.8 \mathrm{~m}$, and a depth of $5.0 \mathrm{~m}$ were set at the roof-fall positions in both the belt conveyor roadway of number 311101 working face and ventilation roadway of number 311102 working face. Apparently, the roadway span near the caves increased significantly, providing advantageous conditions for the fracture and falling of roadway roof. Figure 5 shows the pictures of rooffall scenes in the ventilation roadway of number 311103 working face. To increase the supporting intensity of roadway roof and avoid the second roof-fall accident, single hydraulic props and steel i-beams were added after the first roof-fall accident. Sudden roof-fall accidents in the roadway severely threatened the physical health of underground miners and affected the safe and regular production in mines. Therefore, it is very important to investigate the causes and mechanisms of roadway roof-fall accidents in depth, improve the supporting scheme for surrounding rocks, and optimize the supporting parameters to avoid the reoccurrence of roof-fall accidents.

\section{Occurrence Mechanism of Roof-Fall Accidents in Large-Section Roadways}

3.1. Fracture Characteristics of Roadway Surrounding Rocks. Combined with the tunneling condition in roadway and the mining conditions in working face, a YTJ20 stratum detector as shown in Figure 6 was used for drilling detection on the 


\begin{tabular}{|c|c|c|c|}
\hline $\begin{array}{l}\text { Lithological } \\
\text { geological } \\
\text { column }\end{array}$ & Lithology & $\begin{array}{c}\text { Average } \\
\text { thickness (m) }\end{array}$ & Lithology description \\
\hline 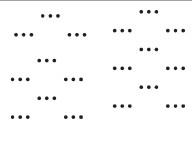 & $\begin{array}{l}\text { Fine } \\
\text { grained } \\
\text { sandstone }\end{array}$ & 11.78 & $\begin{array}{l}\text { Shallow gray, containing cuttings mica, } \\
\text { corrugated and cross-bedding }\end{array}$ \\
\hline$-\frac{--}{-}$ & Mudstone & 6.74 & $\begin{array}{l}\text { Dark gray, quality pure, dense, conchoidal } \\
\text { fracture, containing a small amount of fossil plants }\end{array}$ \\
\hline 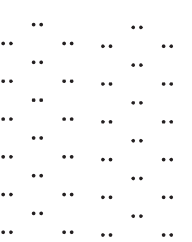 & $\begin{array}{l}\text { Medium } \\
\text { grained } \\
\text { sandstone }\end{array}$ & 15.60 & $\begin{array}{l}\text { Gray, bedding, give priority to quartz, } \\
\text { feldspar, containing cuttings mica, shale } \\
\text { filler content, half hard }\end{array}$ \\
\hline$\frac{\frac{-\cdot-}{\cdot-\cdot} \frac{-\cdot-}{--\cdot}}{\frac{-\cdot-}{\cdot-\cdot}} \frac{-}{\cdot-\cdot}$ & $\begin{array}{c}\text { Sandy } \\
\text { mudstone }\end{array}$ & 5.97 & $\begin{array}{l}\text { Dark gray, horizontal bedding, conchoidal } \\
\text { fracture, containing a small amount of fossil } \\
\text { plants }\end{array}$ \\
\hline & 3-1\#coal & 5.48 & $\begin{array}{l}\text { Black, dark luster, given priority to dark } \\
\text { coal, including fusain, clip clarain lineation, } \\
\text { jagged fracture, dim }\end{array}$ \\
\hline $\begin{array}{ll}\text {-. - } & -\cdot \bar{~} \\
\cdot-\cdot & \cdot-\cdot\end{array}$ & \multirow{3}{*}{$\begin{array}{l}\text { Sandy } \\
\text { mudstone }\end{array}$} & \multirow{3}{*}{7.40} & \multirow{3}{*}{$\begin{array}{l}\text { Dark grey, flaser bedding, containing a } \\
\text { small amount of fossil plants }\end{array}$} \\
\hline$\frac{-\overline{-\cdot-}}{\overline{\cdot-\cdot}}$ & & & \\
\hline$\frac{-\cdot-}{--\cdot-} \frac{-}{\cdot-\cdot}$ & & & \\
\hline 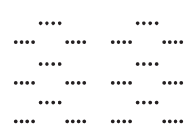 & Siltstone & 9.32 & $\begin{array}{l}\text { Light gray, wavy bedding, including debris } \\
\text { mica, shale filler content, half hard }\end{array}$ \\
\hline
\end{tabular}

FIGURE 2: Lithological characteristics of number 3-1 coal seam, roof, and floor in Bayangaole coal mine.

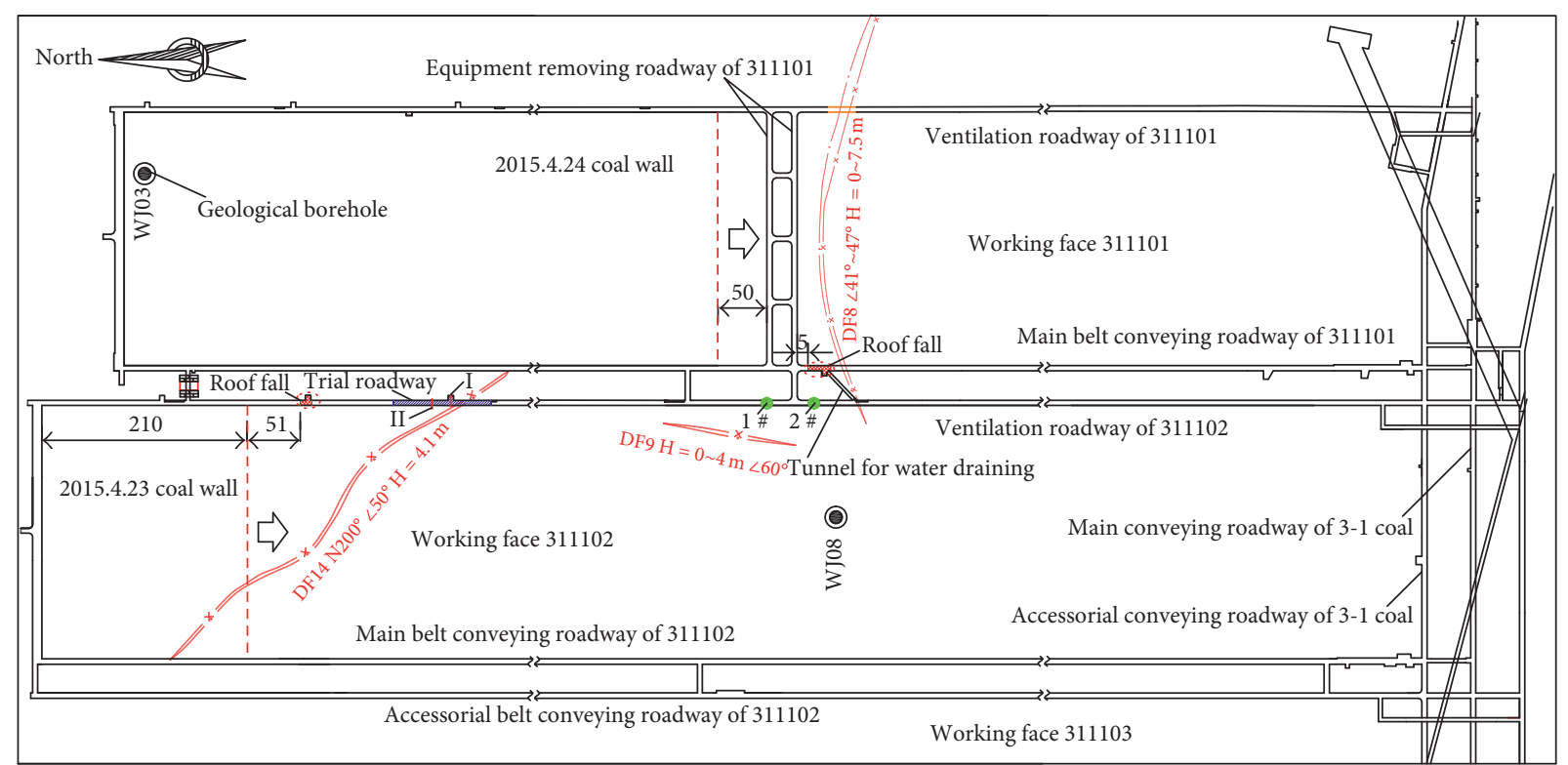

FIGURE 3: Illustration of the arrangement in numbers 311101 and 311102 working faces of Bayangaole coal mine. 


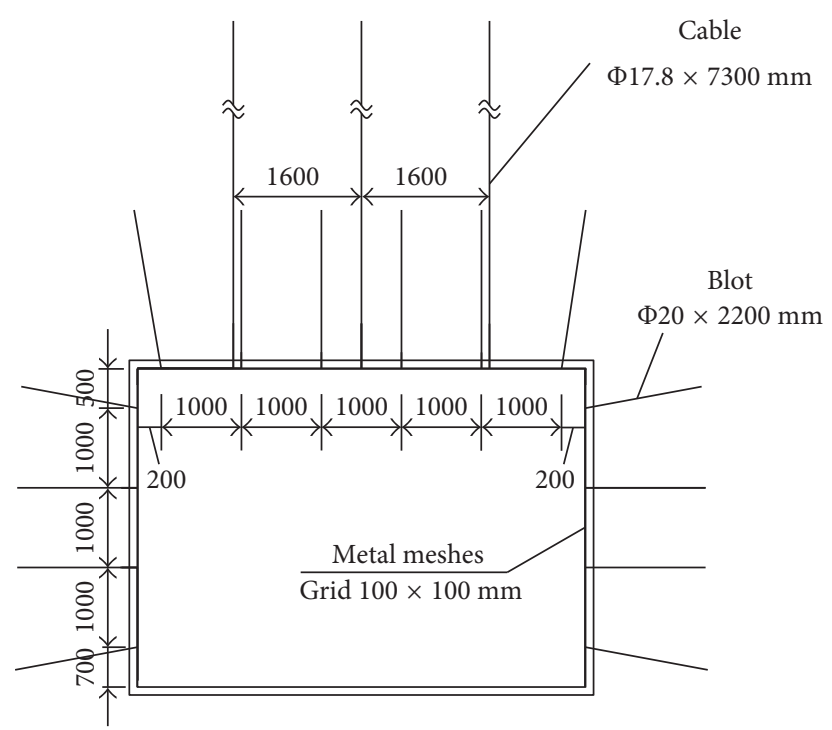

FIGURE 4: Original supporting scheme in the roadway.

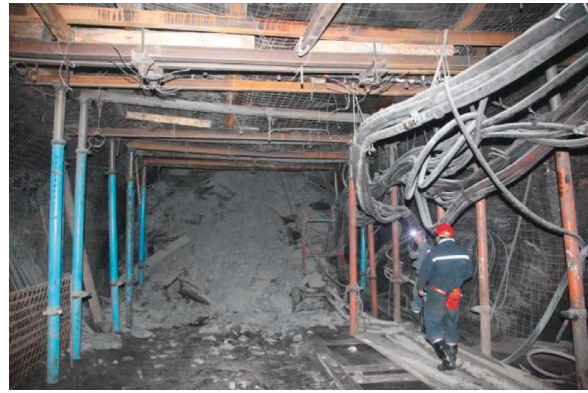

(a)

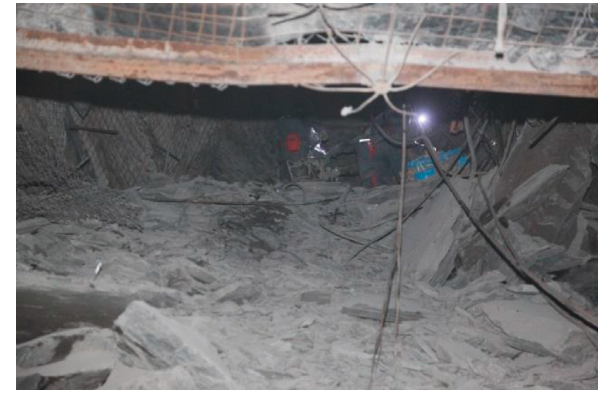

(b)

FIGURE 5: Pictures of rain-fall accidents in the air-return roadway of number 311102 working face.

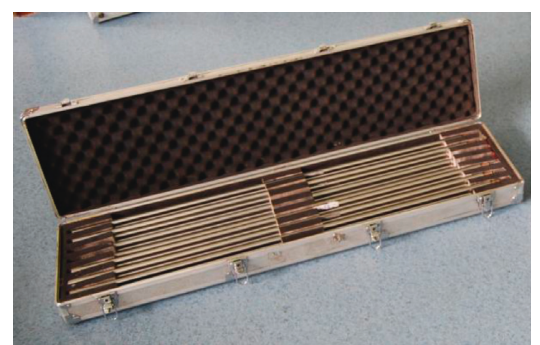

(a)

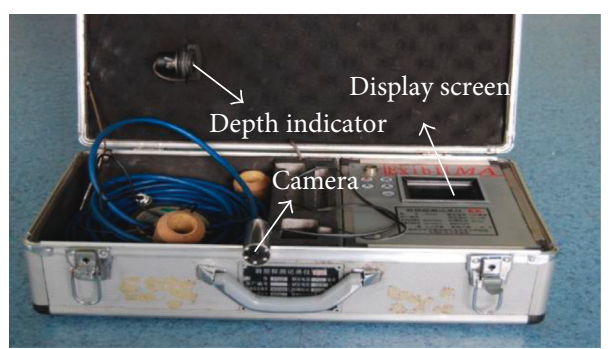

(b)

Figure 6: (a) Picture of guide rod and (b) picture of YTJ20 stratum detector.

fracture characteristics of surrounding rocks in the ventilation roadway of number 311102 working face. During the detection, two monitoring sections were arranged as marked by green dots in Figure 3 on which a total of seven detection drilling holes were arranged. Specifically, four holes were arranged on monitoring section 1 , while three holes were arranged on monitoring section 2. Figure 7 shows the arrangement of each detection hole on the section and related parameters.

Figures 8 and 9 show the drilling TV detection results of different drilling holes on roof and two sides of each monitoring section. The surrounding rocks of roadway exhibited discontinuous failure characteristics, and fractures and crushed zones appeared alternatively and irregularly in the drilling hole with no obvious distribution regularity. According to the development morphology and degree of fractures, the roadway surrounding rocks can be divided into fracture zone, separation zone, and complete zone. Specifically, based on the drilling detection results, the zone along the drilling hole in which no obvious fractures were observed within a continuous range of $30 \mathrm{~cm}$ was defined as the complete zone; the zone in which 1-2 sets of fractures 


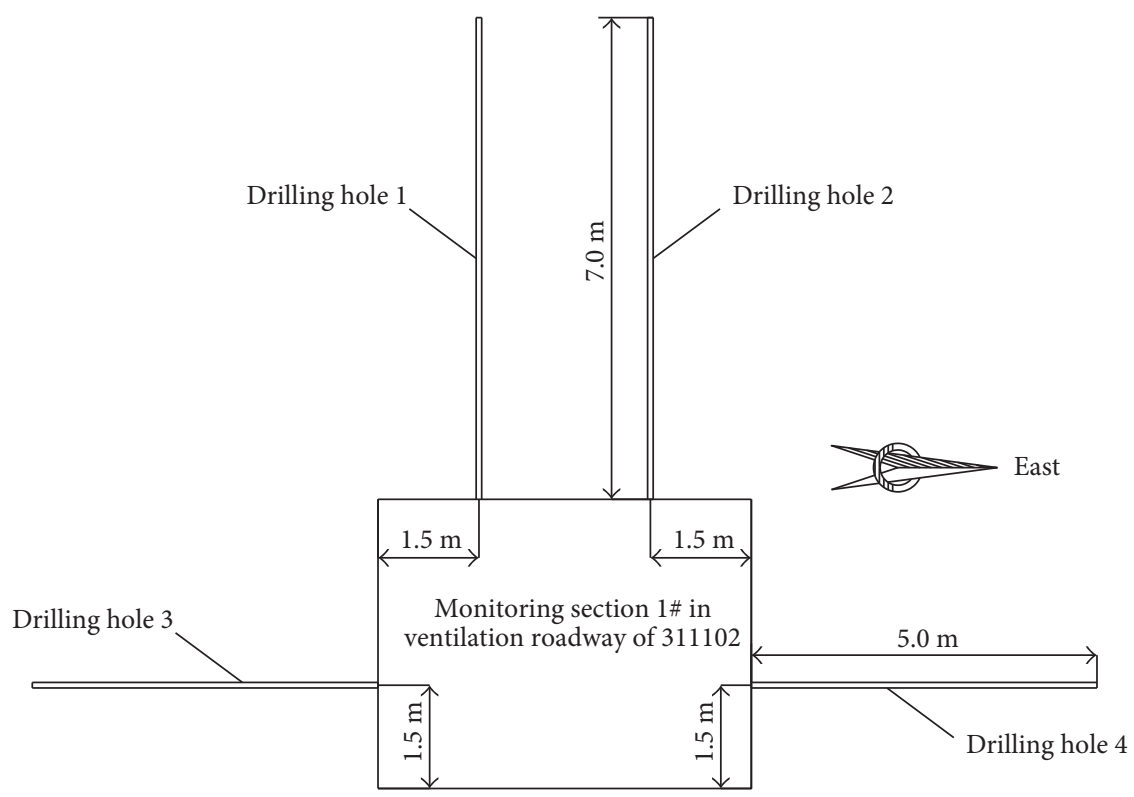

(a)

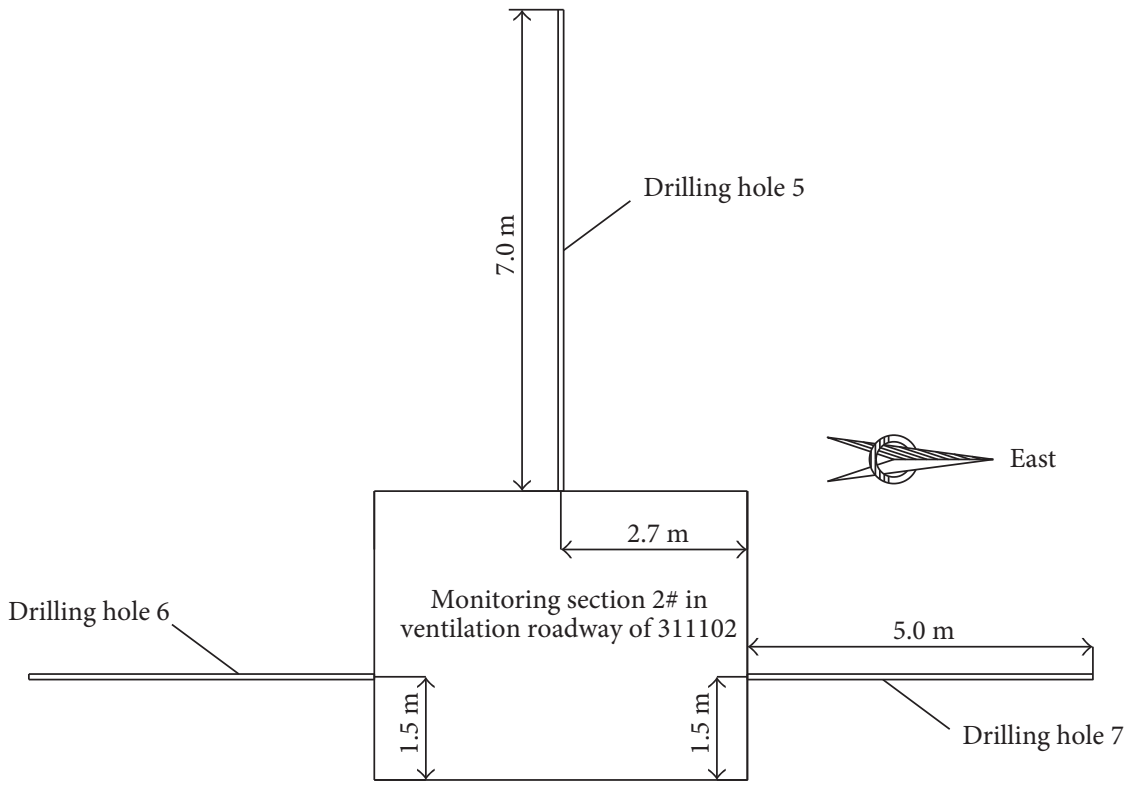

(b)

Figure 7: Arrangement of drilling holes on two monitoring sections and related drilling parameter settings. (a) Monitoring section 1 and (b) monitoring section 2 .

appeared and developed radially along the drilling hole within a continuous range of $30 \mathrm{~cm}$ was defined as the bedding separation zone; the zone in which at least three sets of fractures appeared or crushed was defined as the fracture zone [23]. The range of fracture zone and the maximum development height of bedding separation in the surrounding roadway rocks significantly affected the occurrence of deformation-induced failure and roof-fall disasters [30]. This study used the maximum development depth of fracture or crushing zone in the drilling hole as the maximum destruction range of top and two sides; that is, the maximum destruction ranges of roadway roof and two sides of the roadway were $3.53 \mathrm{~m}$ and $1.36 \mathrm{~m}$, respectively.
Apparently, the roof underwent more severe destruction than the two sides of roadway in both range and degree.

Figures 8(a), 8(b), and 9(a) show that most of the fractures in the drilling holes on roadway roof developed radially, easily leading to roof separation; moreover, the aperture of fracture determined the amount of roof separation. After the roof separation, the full stratum was divided into multiple thin separated sublayers, significantly reducing the stability of roof. Therefore, roof separation is an inducing factor of roof-fall accidents in roadways. By making statistics of the drilling detection results at two monitoring sections, the roof separation and fracture distribution characteristics were concluded, as shown in Figure 10. A lot of separation 


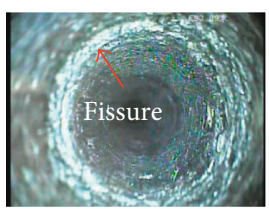

$0.90 \mathrm{~m}$

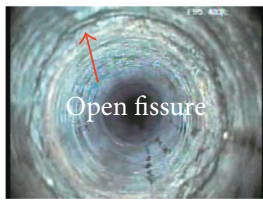

$2.43 \mathrm{~m}$

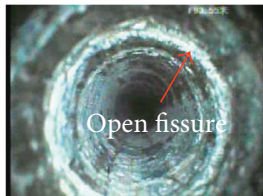

$0.55 \mathrm{~m}$

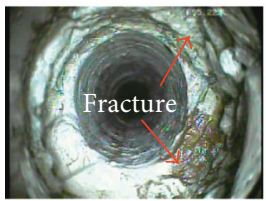

$2.22 \mathrm{~m}$

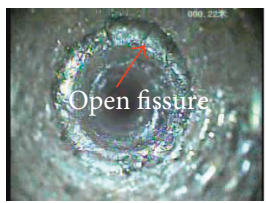

$0.22 \mathrm{~m}$

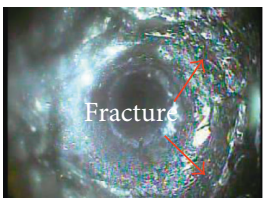

$0.46 \mathrm{~m}$

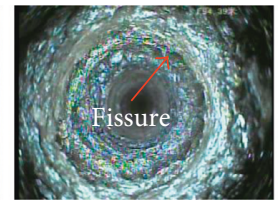

$1.39 \mathrm{~m}$

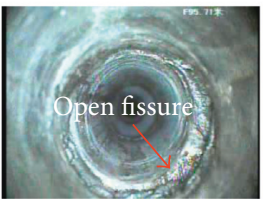

$2.71 \mathrm{~m}$

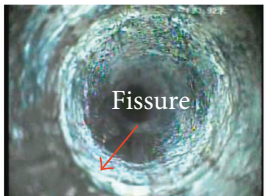

$0.92 \mathrm{~m}$

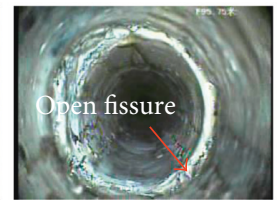

$2.75 \mathrm{~m}$

(b)

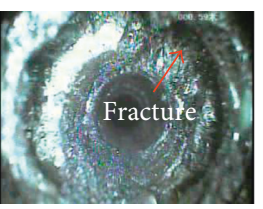

$0.59 \mathrm{~m}$

(c)

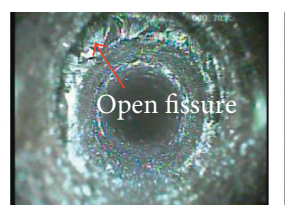

$0.70 \mathrm{~m}$

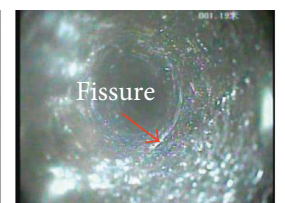

$1.19 \mathrm{~m}$

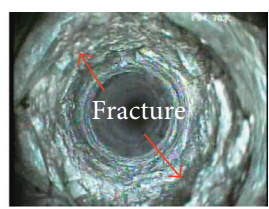

$1.78 \mathrm{~m}$

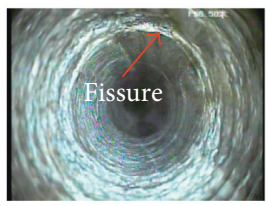

$3.50 \mathrm{~m}$

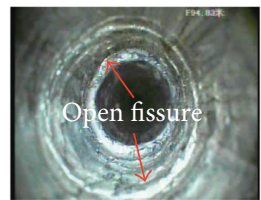

$1.83 \mathrm{~m}$

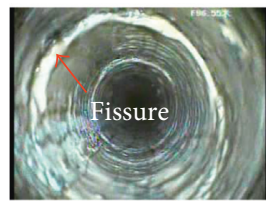

$3.53 \mathrm{~m}$

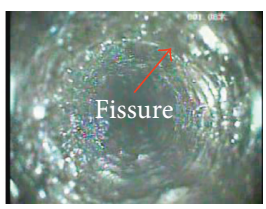

$1.08 \mathrm{~m}$

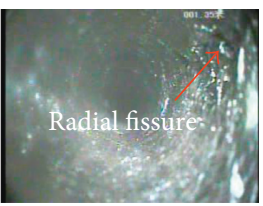

$1.35 \mathrm{~m}$

(d)

FIGURE 8: Detection results of different drilling holes on roof and two sides of monitoring section 1. (a) Observations in drilling hole 1, (b) observations in drilling hole 2, (c) observations in drilling hole 3, and (d) observations in drilling hole 4.

and fracture zones were distributed at intervals within a depth of $3.5 \mathrm{~m}$ near the ventilation roadway of number 311102 working face, while the surrounding rocks at a depth over $3.5 \mathrm{~m}$ were relatively complete and exhibited no obvious fractures and crushes. As stated above, number 3-1 coal seam was 5.48 in thickness, the ventilation roadway of number 311102 working face was advanced along the coal seam floor, and the roadway had a height of $4.2 \mathrm{~m}$. Therefore, the residual coal seam in the roadway was $1.28 \mathrm{~m}$ in thickness. On the roadway roof, the coal seam differed significantly from the sandy mudstone in lithology, resulting in asynchronous wrapping and subsidence of roof and sandy mudstone and easily inducing roof separation. As shown in
Figure 10, obvious roof separations occurred at a depth of 1.3-1.4 $\mathrm{m}$ of the roadway roof. As shown in Figure 3, when roof fall occurred in the main belt conveyor roadway of number 311101 working face, the working face was approximately $85 \mathrm{~m}$ away from the accident. Although number 311101 working face was the first mining face in this mine, the working face exhibited a long arrangement length of approximately $260 \mathrm{~m}$, and the mining-induced stress had a great influence range. Moreover, the roadway where roof fall occurred was near DF8 section. Under the combined effects of mining-induced stress and tectonic stress, the surrounding rocks in the roadway were easily deformed and fractured. Figure 10 clearly shows that under the action of 


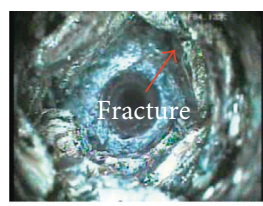

$1.13 \mathrm{~m}$

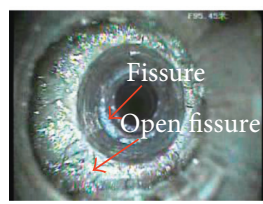

$2.45 \mathrm{~m}$

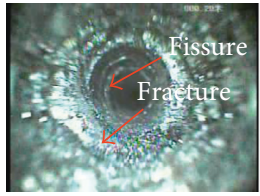

$0.19 \mathrm{~m}$

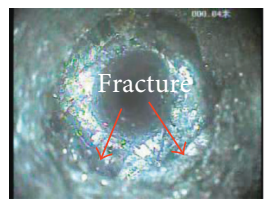

$0.04 \mathrm{~m}$

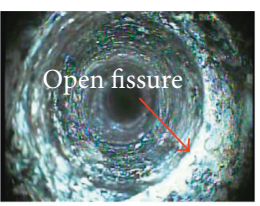

$1.28 \mathrm{~m}$

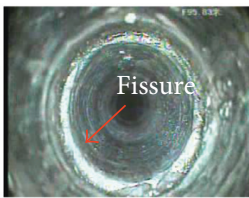

$2.83 \mathrm{~m}$

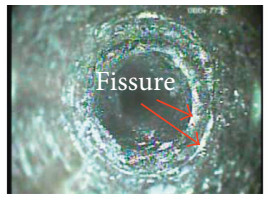

$0.77 \mathrm{~m}$

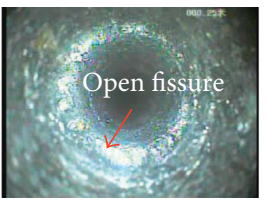

$0.25 \mathrm{~m}$

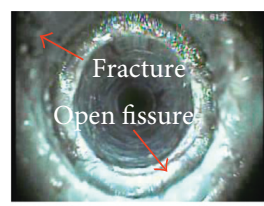

$1.61 \mathrm{~m}$

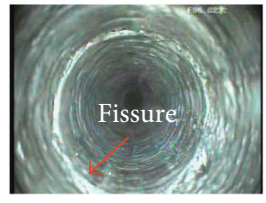

$3.02 \mathrm{~m}$

(a)

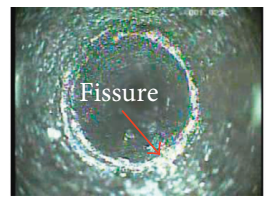

$1.02 \mathrm{~m}$

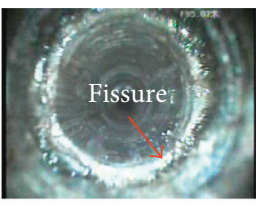

$2.07 \mathrm{~m}$

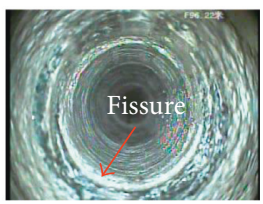

$3.22 \mathrm{~m}$

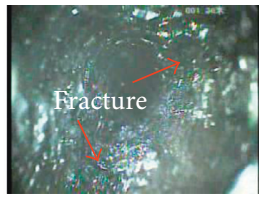

$1.36 \mathrm{~m}$

(b)

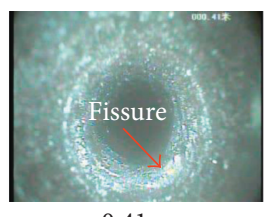

$0.41 \mathrm{~m}$

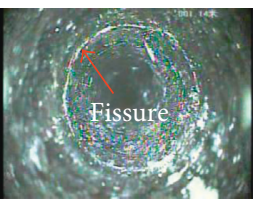

$1.14 \mathrm{~m}$

(c)

Figure 9: Detection results of different drilling holes on roof and two sides of monitoring section 2. (a) Observation in drilling hole 5, (b) observation in drilling hole 6, and (c) observation in drilling hole 7.

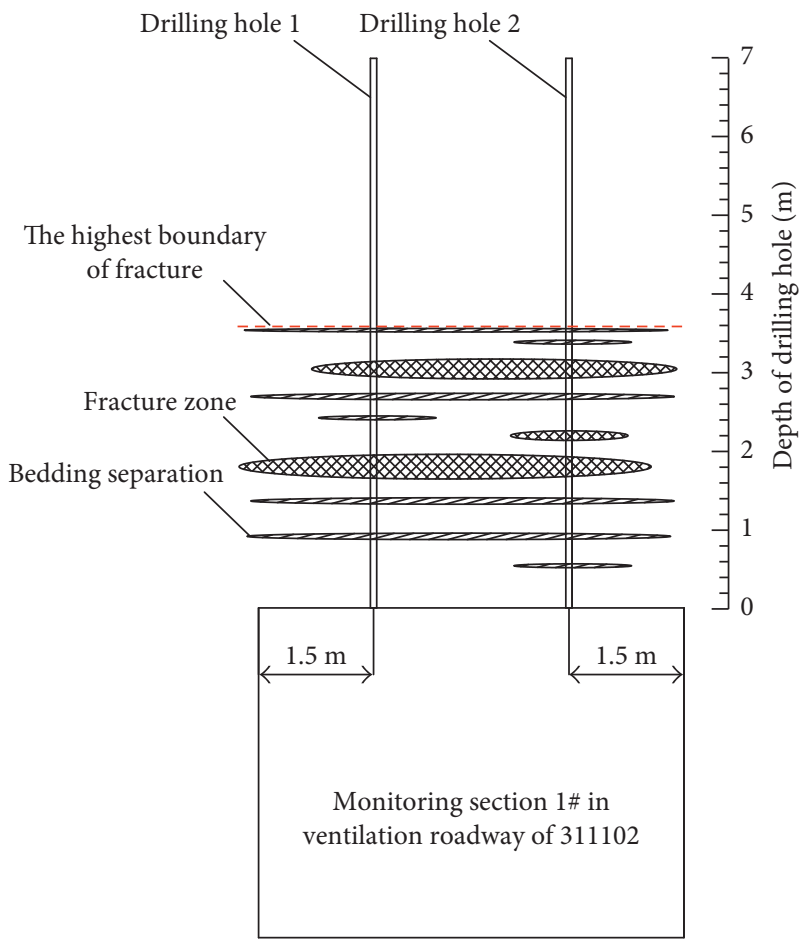

(a)

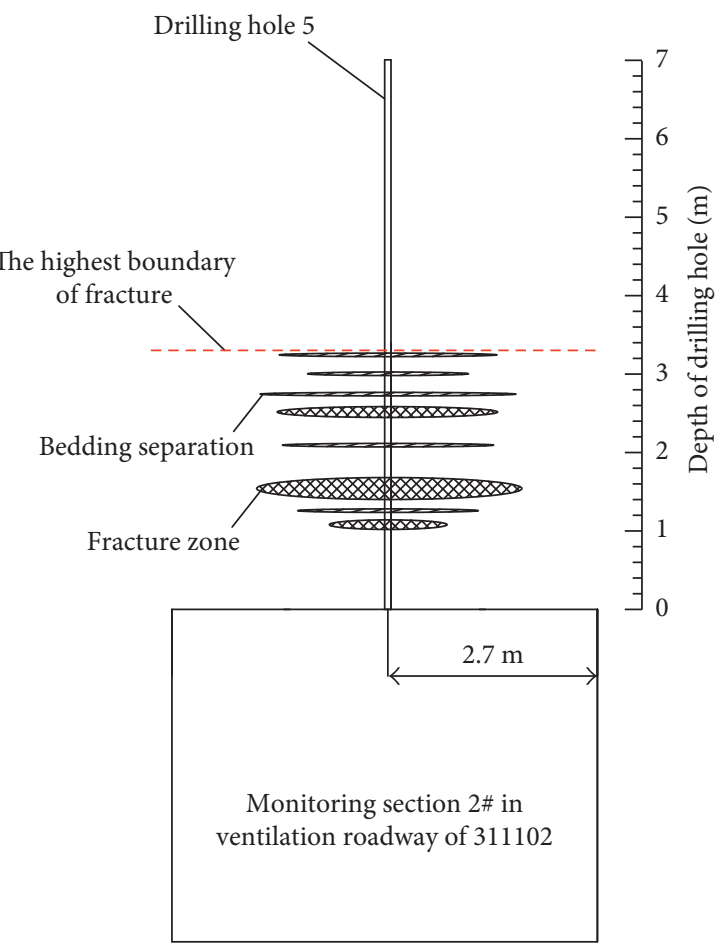

(b)

FIGURE 10: Detection results of roadway roof separation and fracture distribution. (a) Monitoring section 1 and (b) monitoring section 2. 


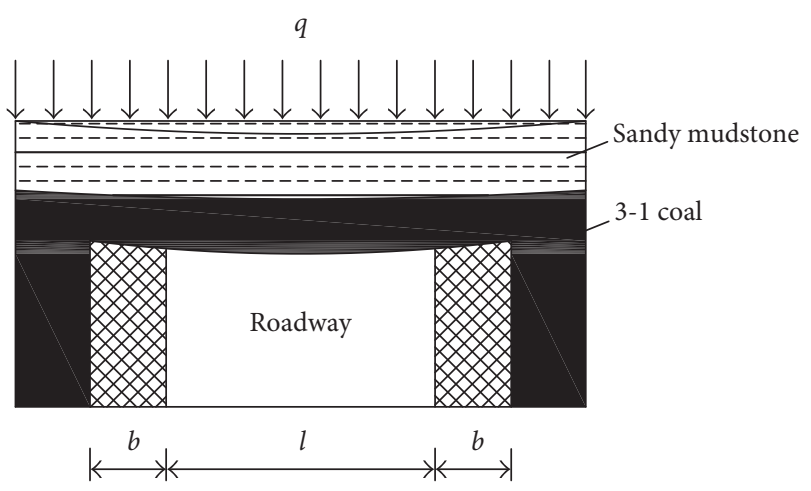

FIgURE 11: Mechanical model of the upper coal roof.

superimposed stresses, many separation and fracture zones appeared in the coal seam on roadway roof, which divided the roof into several separated layers. These layers were all smaller than $1.0 \mathrm{~m}$ in thickness and significantly reduced the stability of stratum in the roadway roof. When the roof-fall accident occurred in the ventilation roadway of number 311102 working face, the working face was only $51 \mathrm{~m}$ away from the accident position. Mining-induced stress is a key factor leading to the occurrence of roof-fall accidents in the roadway, and the secondary mining in number 311102 working face aggravated the deformation and failure of the surrounding rocks in the roadway.

Based on the composite beam theory of anchor blot support, the anchoring force of the bolt increases the contact stress among various rock strata within the anchorage range to avoid the occurrence of stratum separation. Additionally, under the action of anchoring force, the shearing strength between any two rock strata also increases, inhibiting the horizontal diastrophism between any two strata and forming a thick combined rock beam via anchoring within the anchorage range and finally significantly improving the stability of roadway roof [31]. The key of the formation of composite beam is that the anchor bolt provides a sufficient anchoring force. As shown in Figure 4, in the original supporting scheme, both the roof and side anchor bolts were $2.2 \mathrm{~m}$ in length and anchored at the ends with an anchorage length of $1.0 \mathrm{~m}$. During the installation of anchor bolts, the exposure length was generally $10-15 \mathrm{~cm}$, and the anchorage ranges of the original roof and side anchor bolts were at a depth of $1.0-2.0 \mathrm{~m}$ in the surrounding rocks. Figures 8-10 show that the fractures developed well in the roadway roof at a depth range of 1.0-2.0 m; multiple fracture and separation zones were observed. Therefore, the roof bolt cannot be anchored to the full stratum and cannot provide a sufficient anchoring force, causing the failure of anchoring. Afterwards, separation occurred in the coal and rock stratum of roadway roof, and the roof anchor bolts were likely to overall fall off after the fracture. However, the maximum destruction range of the two sides of roadway was only $1.36 \mathrm{~m}$, and the deep surrounding rocks were basically in the complete zone, in which no fractures developed. Therefore, the anchor bolt with a length of $2.2 \mathrm{~m}$ satisfies the requirements of supporting two sides of the roadway.
3.2. Analysis of Roof-Fall Mechanism in the Roadway. Next, the roof-fall mechanism in the roadway was analyzed by taking the ventilation roadway in number 311102 working face as an example. Based on the theory of mechanics of materials, the roof in the ventilation roadway of number 311102 working face was simplified as a simply supported beam, and the mechanical model of rock and beam in the roof was established, as shown in Figure 11. The drilling TV detection results show that the roof anchor bolt was anchored into the full rock stratum and cannot provide a sufficient anchoring force; therefore, the supporting resistance of anchor bolt on the roof stratum can be neglected. In Figure 11, $q$ is the uniformed distributed load on the simply supported beam and mainly includes the gravityinduced stress of rock beam and underlying stratum, and $L$ is the span of the simply supported beam. As shown in Figures 8 and 9 , the coal on the sides of the roadway underwent plastic failure to a certain degree, and fractures developed. Therefore, the bearing capacity was significantly reduced, and the main supports of roof rock beam were no longer located on the sides of the roadway, but moved deep towards the coal. Therefore, $L$ cannot be only set as the roadway width, but should include the depth of plastic zones on two sides of roadway; that is, $L$ can be written as

$$
L=2 b+l,
$$

where $l$ is the roadway width and $b$ is the depth of the plastic zone on two sides of roadway.

According to the theory in mechanics of materials, the maximum bending deformation and maximum tensile stress exist at the center of a simply supported beam. When the applied maximum tensile stress on the roof rock beam reached the stratum's tensile strength, the rock beam snapped. The limit span when a simply supported beam with a unit width fractured can be calculated as follows:

$$
L_{\max }=2 h \sqrt{\frac{\sigma_{\mathrm{t}}}{3 q}}
$$

where $h$ is the thickness of the roof stratum with a unit of $m$ and $\sigma_{t}$ is the stratum's uniaxial tensile strength with a unit of $\mathrm{MPa}$.

The actual load on the rock stratum includes not only the gravity of rock stratum but also the load induced under stratum. Based on the principle of composite beam, considering the effect of overlying $k$ th stratum, the applied load on the first stratum can be written as follows [32]:

$$
\left(q_{k}\right)_{1}=\frac{E_{1} h_{1}^{3}\left(\gamma_{1} h_{1}+\gamma_{2} h_{2}+\cdots+\gamma_{k} h_{k}\right)}{E_{1} h_{1}^{3}+E_{2} h_{2}^{3}+\cdots+E_{k} h_{k}^{3}},
$$

where $E_{i}, \gamma_{i}$, and $h_{i}$ are the elastic modulus, body force, and thickness of the $i$ th stratum $(i=1,2, \ldots, k)$.

As shown in Figure 2, the immediate roof of the roadway was the residual coal seam, the second stratum was mainly composed of sandy mudstone above the coal seam, and the third stratum was mainly composed of medium sandstone in the main roof. According to the mechanical test results of rock, the unit weights of number 3-1 coal seam, sandy mudstone, and medium sandstone denoted as $\gamma_{1}, \gamma_{2}$, and $\gamma_{3}$ 
were $13.5 \mathrm{kN} / \mathrm{m}^{3}, 26.0 \mathrm{kN} / \mathrm{m}^{3}$, and $26.8 \mathrm{kN} / \mathrm{m}^{3}$, respectively. The uniaxial tensile strengths of these three strata denoted as $\sigma_{1}, \sigma_{2}$, and $\sigma_{3}$ were $1.1 \mathrm{MPa}, 2.0 \mathrm{MPa}$, and $4.5 \mathrm{MPa}$, respectively. The elastic moduli of these three strata denoted as $E_{1}, E_{2}$, and $E_{3}$ were $3.47 \mathrm{GPa}, 7.5 \mathrm{GPa}$, and $14.3 \mathrm{GPa}$, respectively. The average thicknesses of the second and third strata consisting of sandy mudstone and medium sandstone were $5.97 \mathrm{~m}$ and $15.60 \mathrm{~m}$, respectively. Apparently, both of these strata were quite thick, whose elastic moduli far exceeded that of the top coal seam. Therefore, the load on the roof beam can be calculated if the self-loading $\left(q_{1}\right)_{1}$ of coal seam roof is known.

$h_{1}$ is the thickness of the residual coal seam in the roadway roof and set as $1.28 \mathrm{~m}$ in this study. According to (2), the limit span when the coal seam in the roadway roof fractured was $11.8 \mathrm{~m}$; however, this calculation did not consider many factors including the separation and fracture in roof coal seam, mining-induced disturbance, and crustal stress. Actually, the limit span of roof coal seam was smaller than $11.8 \mathrm{~m}$. According to the drilling TV detection results, the maximum depth of the plastic zone in roadway side was $1.36 \mathrm{~m}$ (i.e., $b=1.36 \mathrm{~m}$ ). As shown in (1), the actual span of the coal seam on roadway roof was $8.12 \mathrm{~m}$. Accordingly, under normal circumstances, the actual span of coal seam in the roadway roof was smaller than the limit span when fracture occurred, and the roof coal seam exhibited no fracture and failure, indicating that no roof-fall accidents occurred in the roadway.

As shown in Figure 3, two caverns with an identical depth of $5.0 \mathrm{~m}$ existed at the roof-fall positions in the main belt conveyor roadway of number 311101 working face and the ventilation roadway of number 311102 working face. The existence of caverns on the sides of roadway increased the span of roof coal seam, and the span of roof coal seam where the cavern was located can be written as follows:

$$
L=2 b+l+l_{\mathrm{d}}
$$

where $l_{\mathrm{d}}$ is the depth of cavern on the sides of roadway with a unit of $\mathrm{m}$.

According to (4), it can be easily concluded that the practical span of roof coal seam at the cavern position was $13.12 \mathrm{~m}$, which was greater than the limit span when the fracture occurred; therefore, the coal seam in roadway roof was fractured.

According to the abovementioned drilling TV detection results, several obvious separation failures appeared in the roof at a depth below $3.53 \mathrm{~m}$, separating the rock stratum $2.25 \mathrm{~m}$ below the sandy mudstone from the above stratum, and an obvious stratification was observed. In contrast, as shown in Figure 10, the stratum $3.72 \mathrm{~m}$ above the sandy mudstone was relatively complete. The stratum at a thickness of $2.25 \mathrm{~m}$ above the sandy mudstone was divided by the stratum into several sublayers, and the thickness of each sublayer was not more than $1.0 \mathrm{~m}$. When the sublayer of sandy mudstone was $1.0 \mathrm{~m}$ in thickness, the limit fracture span of sandy mudstone sublayer was $10.1 \mathrm{~m}$. The calculation is similar to that of the limit fracture span of top coal seam. When the top coal seam around the cavern in roadway was
TABLE 1: Cable parameters in original support.

\begin{tabular}{lc}
\hline Properties & Values \\
\hline Diameter $(\mathrm{mm})$ & 17.8 \\
Length $(\mathrm{mm})$ & 7300 \\
Elastic modulus (GPa) & 237 \\
Tensile strength of steel strand (MPa) & 1860 \\
Maximum tensile load (kN) & 353 \\
Elongation (\%) & 4 \\
Pre-tension (kN) & 0 \\
\hline
\end{tabular}

fractured, the actual span of the sandy mudstone sublayer also exceeded the limit fracture span, and therefore the sandy mudstone sublayer was also fractured. The residual sublayer above the sandy mudstone sublayer was $3.72 \mathrm{~m}$ in thickness. Similarly, the limit fracture span of this sublayer was also calculated to be $19.5 \mathrm{~m}$, far exceeding the stratum's actual span, and no fracture occurred in this sublayer.

According to the above analysis, the top coal seam around the cavern in roadway and the sandy mudstone layer at a thickness of $2.25 \mathrm{~m}$ satisfied the condition of fracture failure and were likely to fracture. When the top coal seam was fractured, the load on the stratum was bore by the anchor cable for suspension. Therefore, the load on each anchor cable when the fracture occurred in the top coal seam can be estimated using the following formula:

$$
P_{\mathrm{c}}=d_{\mathrm{s}} d_{\mathrm{r}} h_{\mathrm{fc}} \gamma_{1}+d_{\mathrm{s}} d_{\mathrm{r}} h_{\mathrm{fm}} \gamma_{2}
$$

where $d_{\mathrm{s}}$ and $d_{\mathrm{r}}$ are the spacing and array pitch between the arranged anchor cables with a unit of $\mathrm{m} ; h_{\mathrm{fc}}$ and $h_{\mathrm{fm}}$ are the thicknesses of top coal seam and sandy mudstone when the fracture occurred with a unit of $\mathrm{m}$. According to the arrangement of anchor cables, $d_{\mathrm{s}}=1.6 \mathrm{~m}$ and $d_{\mathrm{r}}=3.0 \mathrm{~m}$. Based on the drilling TV detection results, the maximum development height when the separation layer in roadway roof was fractured was $3.53 \mathrm{~m}$; specifically, it included the top coal seam at a thickness of $1.28 \mathrm{~m}$ and a sandy mudstone layer at a thickness of $2.25 \mathrm{~m}$, that is, $h_{\mathrm{fc}}=1.28 \mathrm{~m}$ and $h_{\mathrm{fm}}=2.25 \mathrm{~m}$. According to (5), the load on each anchor cable was $363.74 \mathrm{kN}$.

In the original supporting scheme, steel strand anchor cables with a nominal diameter of $17.8 \mathrm{~mm}$ were used, and the parameters are listed in Table 1. Using the original supporting scheme, the maximum tensile load of the anchor cable was $353 \mathrm{kN}$, smaller than the applied load $(363.74 \mathrm{kN})$; therefore, the anchor cable snapped. Afterwards, the fractured top stratum lost the support, thus inducing the rooffall accident in the roadway.

Based on the above analyses, roof-fall accidents in the main belt conveyor roadway of number 311102 working face and ventilation roadway of number 311102 working face can be attributed to the following three aspects:

(1) Stress condition is a key factor in the occurrence of roof-fall accident in the roadway. Under the combined effect of mining-induced stress and tectonic stress, the surrounding rocks in the roadway exhibited severe deformation and destruction, the roof was broken, and the stratum was separated. 
These are the preconditions for the occurrence of roof-fall accident in the roadway.

(2) Because of the existence of equipment caverns, the actual span of the roof stratum increased significantly, also providing favorable conditions for the occurrence of fracture and failure of roof stratum in the roadway.

(3) The original supporting scheme is unreasonable, where the anchor bolts in the roadway roof were short and the fractures developed in the surrounding rocks within the anchorage range, thus leading to an insufficient anchoring force. Therefore, the appearance of separation of coal seam and stratum in roadway roof could be hardly suppressed, and the role of the anchor bolt support as the composite beam could be hardly fully played. In addition, the array pitch between anchor cables was too high, and the used anchor cables were poor in specifications and models. Therefore, an insufficient limit tensile load of the anchor cable could hardly support the gravity load of the fractured stratum and easily induced tensile failure.

\section{Optimization of Supporting Design}

Using the original supporting scheme, many severe roof-fall accidents occurred in the large-section mining roadway. By analyzing the occurrence mechanism of roof-fall accidents in the roadway, it was found that the original support design and related parameter setting were unreasonable, lacking some targeted control measures according to the roadway roof's deformation failure characteristics. To avoid the recurrence of roof-fall accident in the roadway, a more reasonable supporting scheme should be proposed to better control the roof deformation and instability in the roadway. Based on the abovementioned analysis results on the occurrence mechanisms of roof-fall accidents in large-section mining roadway and many successful experiences of roadway support in China's mines, the following points should be considered while designing a novel roadway support scheme:

(1) The support should be rapidly installed after the roadway excavation [33]. Under the action of excavation-induced stress concentration, the surrounding rocks in the roadway may easily be deformed and fractured. Without timely support, the surrounding rocks showed yield failure too early, and the yield zone further expanded, finally causing the loss of strength of surrounding rocks and the failure of support. In particular, for the roadway roof with a poor lithology, roof support should be completed in real time after excavation to avoid the occurrence of premature separation and failure.

(2) The anchor cable's supporting performance should be guaranteed. In the support system of roadway surrounding rocks, anchor cables were always used for overhanging. The failure of anchor cables in support is a key factor that leads to the occurrence of roof-fall accidents. First, the anchor cables should be long enough and fixed into a complete and hard stratum so that they cannot be dragged. Second, the anchor cable's model should match well with the length, and the cable's limit tensile load should exceed the gravity of the stratum within the supporting range to avoid the occurrence of tensile failure.

(3) The anchor bolt should be grouted in full length. After the excavation in the large-section roadway, under the combined action of mining stress and tectonic stress, the surrounding rocks were severely destroyed, and both fracture and separation zones were developed in the stratum within the anchoring range. The traditional end-anchorage method should anchor the end of the bolt into the full stratum to fully play the bolt's supporting and reinforcement function; in cases when the roof was water-rich and severely destroyed, the end-anchorage method could hardly accurately anchor to the full region in the stratum, easily causing the invalidation of anchorage and thus triggering roadway instability. In these cases, the bolt should be installed using full-length anchorage so that the invalidation of anchorage can be avoided and the supporting performance can be effectively enhanced. Additionally, full-length anchorage further increases the anchor bolt's shearing resistance capability; in the region with more severe separation, this anchorage mode effectively prevents the relative lateral deformation among the roof sublayers [34].

(4) The pre-tension in cable supporting should be increased. According to the field monitoring results, after the excavation in the large-section roadway, the roof stratum was separated into multiple thin sublayers. These thin sublayers were more easily bent, fractured, and even fell than a complete stratum. During the installation, a great pretightening force should be first applied on the cable. Research showed that great pretightening force could increase frictional resistance along bedding planes and prevent the separation failure in the stratum [35]. The separated thin sublayers can be tightened again for forming a thick combined stratum, thus enhancing the stability of the stratum [36].

With these considerations in mind, a new supporting scheme is proposed in this study for overcoming roof-fall accidents in large-section roadways. Figure 11 shows the arrangement of anchor bolts and cables. The length of roof anchor cable in the roadway can be estimated using the following formula:

$$
L=L_{1}+L_{2}+L_{3}+L_{4}
$$

where $L_{1}$ is the thickness of top coal seam in the roadway, $L_{2}$ is the thickness of sandy mudstone layer above the coal seam, $L_{3}$ is the anchor cable's anchorage length into the stratum and generally set as $1.5 \mathrm{~m}$, and $L_{4}$ is the anchor cable's exposure length and generally set as $0.3 \mathrm{~m}$. 
TABLE 2: Cable parameters in new support.

\begin{tabular}{lc}
\hline Properties & Values \\
\hline Diameter $(\mathrm{mm})$ & 21.8 \\
Length $(\mathrm{mm})$ & 9000 \\
Elastic modulus $(\mathrm{GPa})$ & 237 \\
Tensile strength of steel strand $(\mathrm{MPa})$ & 1860 \\
Maximum tensile load $(\mathrm{kN})$ & 607 \\
Elongation $(\%)$ & 7 \\
Pre-tension $(\mathrm{kN})$ & 200 \\
\hline
\end{tabular}

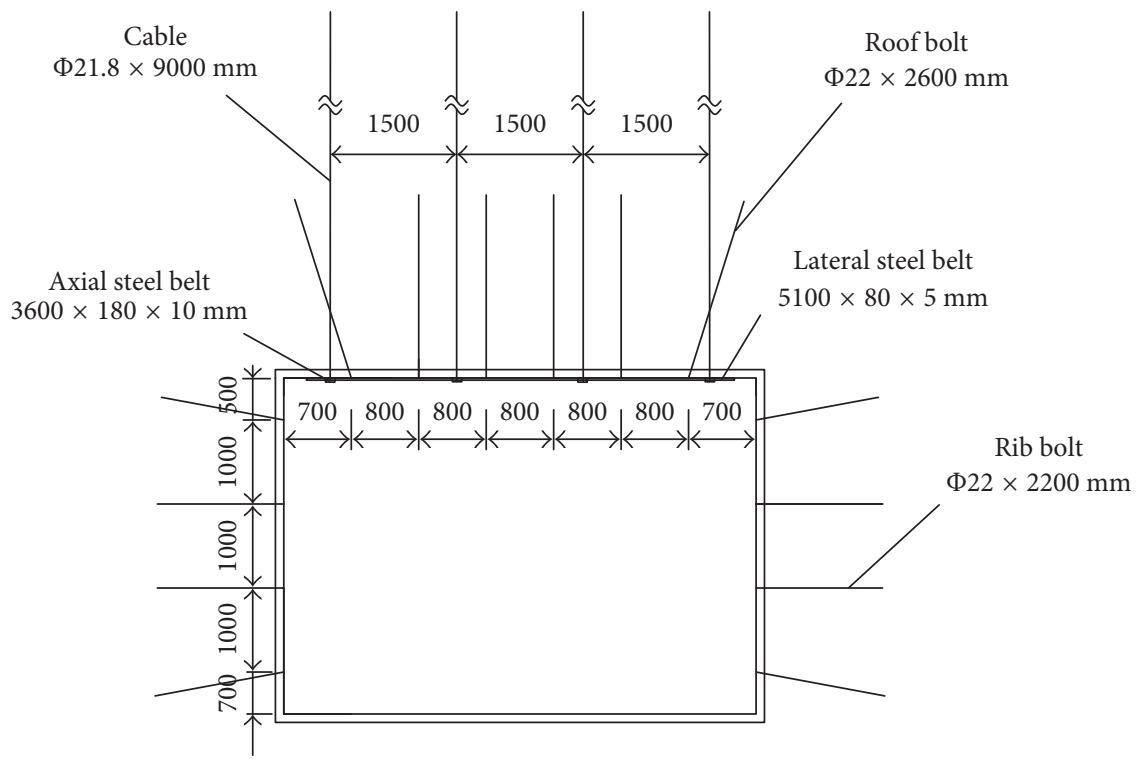

FIGURE 12: New supporting design in the roadway.

Based on the actual condition of both roof and floor strata in number 3-1 coal seam, $L_{1}$ and $L_{2}$ were set as $1.28 \mathrm{~m}$ and $5.97 \mathrm{~m}$, respectively. Therefore, according to (6), $L=9.05 \mathrm{~m}$. Table 2 shows the detailed parameters of anchor cables in the new supporting scheme.

Compared to the original support in roadway, the designed new support system did not change the side support but only modified the top support. As shown in Figure 12, the new roof support included three anchor cables, six bolts, and crisscrossed steel belts. The roof blot was $22 \mathrm{~mm}$ in diameter and $2.6 \mathrm{~m}$ in length, while both the spacing and array pitch were set as $0.8 \mathrm{~m}$. The resin was poured into the entire drilling hole to achieve the bolt's fulllength anchorage. The top anchor cable was $21.8 \mathrm{~mm}$ in diameter and $9 \mathrm{~m}$ in length (the calculation results according to (6)), while the spacing and array pitch in installation were $1.5 \mathrm{~m}$ and $1.6 \mathrm{~m}$, respectively. The end of the anchor cable was also anchored with the resin with an anchorage length no less than $1.5 \mathrm{~m}$. The anchor cables on the surface of the surrounding rocks were fixed with metal floor plates and nuts; moreover, a pretightening force of not less than $200 \mathrm{kN}$ was applied on each anchor cable.

The installation effect of the anchor cable determines the suppression performance of roof-fall accidents in largesection roadways. Table 2 shows the detailed parameters of anchor cables in the new supporting scheme. The limit tensile load of the anchor cable in the new supporting scheme was as high as $607 \mathrm{kN}$, far exceeding the weight of the stratum within the support range. Thus, the tensile failure of the anchor cable can be effectively avoided. In addition, the connecting bolts and steel bands for anchor cable support were installed on the roadway roof. Specifically, the steel bands were arranged in a crisscross pattern to increase the supporting area on roof and effectively prevent roof fall.

\section{Field Test and Monitoring}

To validate the effectiveness of the new designed support, a field test was performed in the ventilation way of number 311102 working face of Bayangaole coal mine. A test section at a length of $100 \mathrm{~m}$ in the roadway was selected $150 \mathrm{~m}$ in front of the working face along the advancing direction, and a new support was installed according to the new design scheme. Two monitoring sections (sections I and II) with a spacing of $20 \mathrm{~m}$ were set in the test section for tests. An equipment cavern was arranged on the side of the roadway in section $\mathrm{II}$, whose size was the same as that of the cavern at roof-fall accident. Figure 3 shows the position of the test section and monitoring sections. During the tests, the roof stratum deformation and force on blot were monitored using multipoint extensometers and 
stressmeters. On each monitoring section, a multipoint extensometer, an anchor cable stressmeter, and a bolt stressmeter were installed on the roadway roof; the multipoint extensometer included four anchor points with installation depths of $2 \mathrm{~m}, 4 \mathrm{~m}, 6 \mathrm{~m}$, and $8 \mathrm{~m}$, respectively. Figure 13 shows the monitor design. The roof extensometer has a measuring precision of $0.2 \mathrm{~mm}$, while the stressmeter has a measuring precision of $0.2 \mathrm{MPa}$.

During the installation of measuring instruments on two monitoring sections, the section in the roadway was already excavated, and the initial deformation of the roadway was already released. Thus, the measuring instruments can only measure the roof deformation and anchor cable (bolt) change in the roadway during the period when subjected to mining in the face. After the installation, the measuring instruments started monitoring until the working face passed the monitoring section. The monitoring lasted approximately 70 days, and the working face was advanced at a velocity of $2.8 \mathrm{~m} /$ day.

Figures 14 and 15 show the monitoring results of roof deformation and the stress on anchor cable (bolt) on sections I and II, respectively. When the measuring point was in front of the working face, the distance between this measuring point and the working face was negative. According to the monitoring results, by using the new roof supporting scheme, the roof's deformation was effectively controlled, and the roof maintained favorable integrity during the working face's advance. When the working face moved to the monitoring section, the roof displacement reached the maxima. Specifically, the roof displacements at sections I and II were $143 \mathrm{~mm}$ and $204 \mathrm{~mm}$, respectively, far smaller than the allowable deformation. The roadway roof mainly underwent a deformation of $0-4 \mathrm{~m}$ above the roof, where the ratio of roof displacement exceeded $85 \%$ of the total roof displacement; within the range of 4-6 $\mathrm{m}$ above the roof, the roof showed a slight displacement. Finally, the roof displacement 6-8 $\mathrm{m}$ above the roof can be neglected.

As the displacement of the shallow stratum (within a range of 0-4 $\mathrm{m}$ above the roof) increased gradually, stresses on the bolt at both sections I and II increased, indicating that a bolt with full-length anchorage can effectively suppress the displacement of a shallow stratum on the roof. The stress on roof anchor cable also increased with the increase in roof displacement and reached the maximum when the working face moved to the measuring point. The maximum stresses on roof anchor cables on sections I and II were $39.3 \mathrm{MPa}$ and $52.5 \mathrm{MPa}$, respectively. According to the forced area of the stressmeter, the forces on the anchor cables were $275 \mathrm{kN}$ and $365 \mathrm{kN}$, respectively, far smaller than the anchor cable's tensile load limit. This indicates that the used anchor cable was reasonable.

Section II was located in the roadway's equipment cavern with a large span, also close to DF14 section. Therefore, the maximum roof displacement on section II was higher than that on section I; moreover, as shown in Figure 15(b), the roof displacement mainly appeared in the shallow stratum $2-4 \mathrm{~m}$ above the roof. This indicates that due to the effect of mining, great separation and failure appeared above the roof outside the bolt's anchorage range;

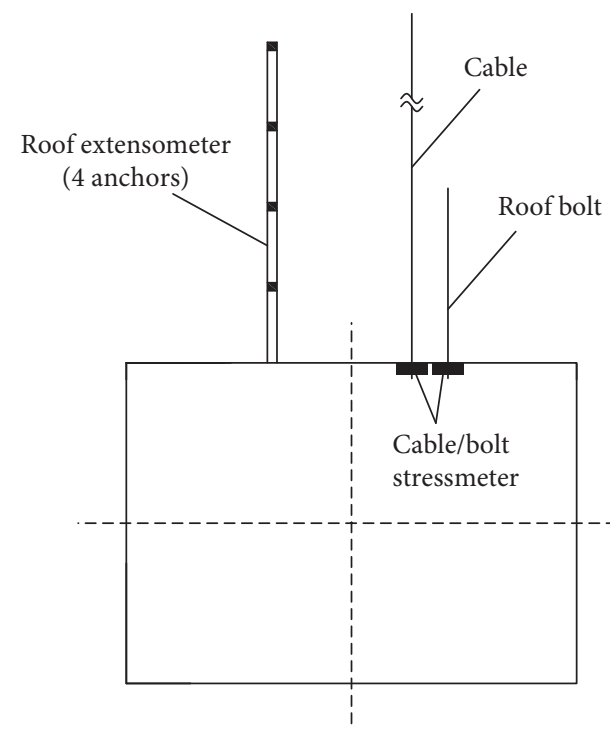

FIgure 13: Monitoring design.

however, the existence of high-strength anchor cable effectively prevented the further development of separation and failure, so that roof-fall accidents can be avoided. The maximum stress on roof anchor cable at section II also far exceeded that at section I, also proving the abovementioned conclusion.

Additionally, as shown in Figures 14 and 15, when the working face was $100 \mathrm{~m}$ away from the measuring point, the displacement of roadway roof started to increase, and the stress on anchor cable (bolt) significantly increased, indicating that the mining-induced stress affected the range $100 \mathrm{~m}$ in front of the working face. At section I, when the working face was located $50 \mathrm{~m}$ away from the measuring point, the roof displacement rapidly increased; at section II, the roof displacement sharply increased when the working face was $62 \mathrm{~m}$ away from the measuring point. It can thus be inferred that the advanced support provided a significant effect within the range 50-60 $\mathrm{m}$ in front of the working face. Thus, during the working face's advance, an advanced support should be set $60 \mathrm{~m}$ in front of the working face to strengthen the supporting intensity on the roadway roof. In the cases when some geological structures such as faults exist in front of the working face, the range of advanced support should be appropriately increased.

\section{Conclusions}

This study focused on a coal seam in a large-section roadway of Bayangaole coal mine, Inner Mongolia, China, and investigated the occurrence mechanism of mining-induced roof-fall accidents and related supporting methods. The long-wall mining method was used in numbers 311101 and 311102 working faces for coal extraction. During the mining, severe roof-fall accidents occurred in these two working faces, which have caused severe impacts on the life safety of miners and production activities.

The fracture characteristics of the surrounding rocks in the ventilation roadway of number 311102 working face 


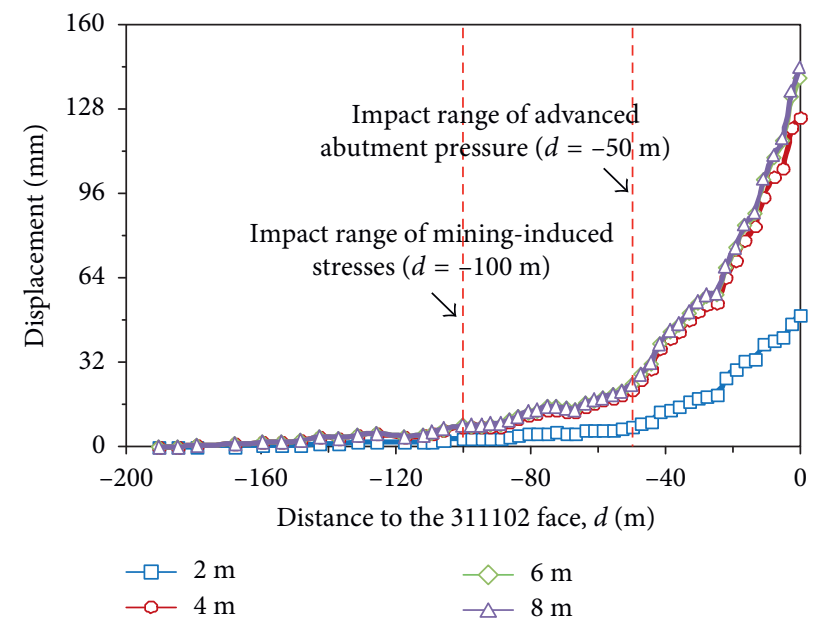

(a)

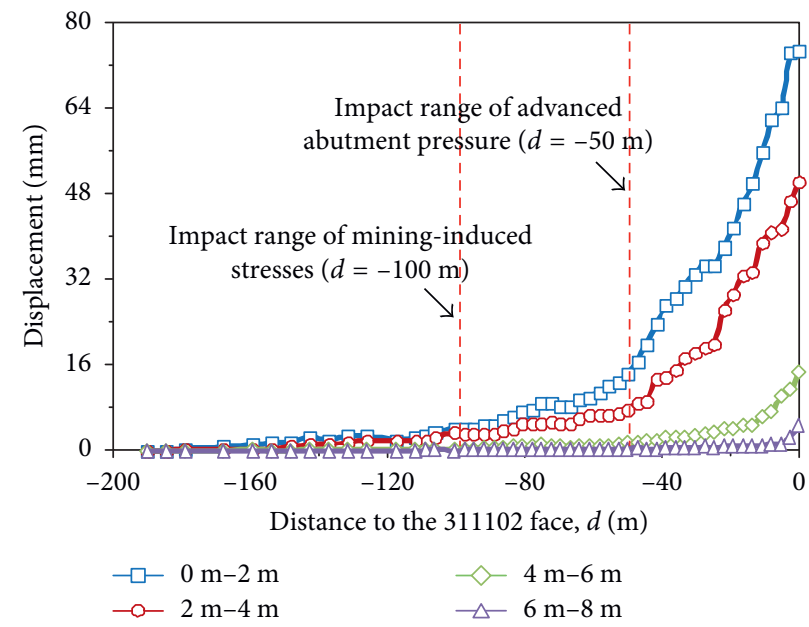

(b)

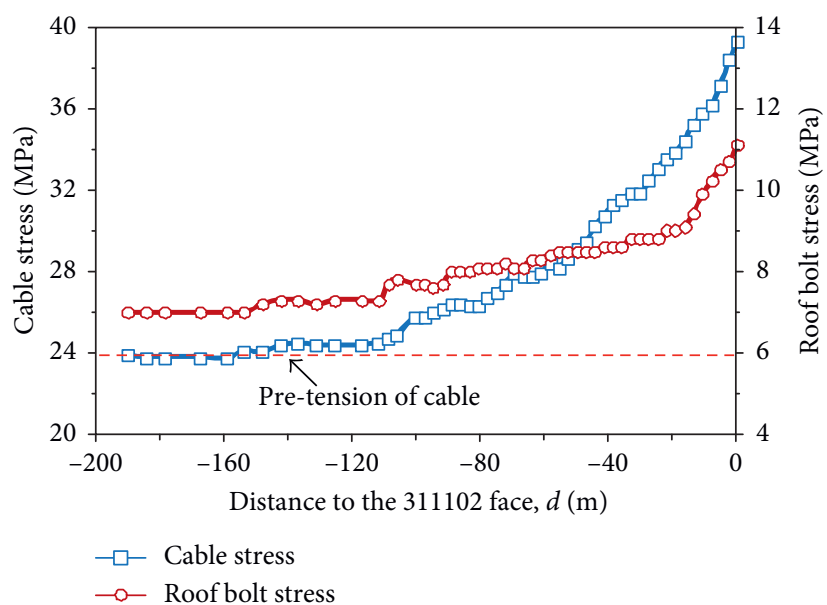

(c)

FIgURE 14: Monitoring results of roof displacement and stress on anchor cable (bolt) at section I. (a) Monitoring results of roof displacement, (b) displacements of roof stratum at different depths, and (c) monitoring results of stress on anchor cable (bolt).

were evaluated using a stratum detector. The results show that the surrounding rocks of roadway exhibited a discontinuous failure; fracture and crushed zones appeared in the drilling holes alternately and irregularly. The maximum fracture ranges of the roadway roof and side were $3.53 \mathrm{~m}$ and $1.36 \mathrm{~m}$, respectively; apparently, the destruction on roadway roof far exceeded that on two sides of the roadway in both range and degree. The interval distribution of separation 


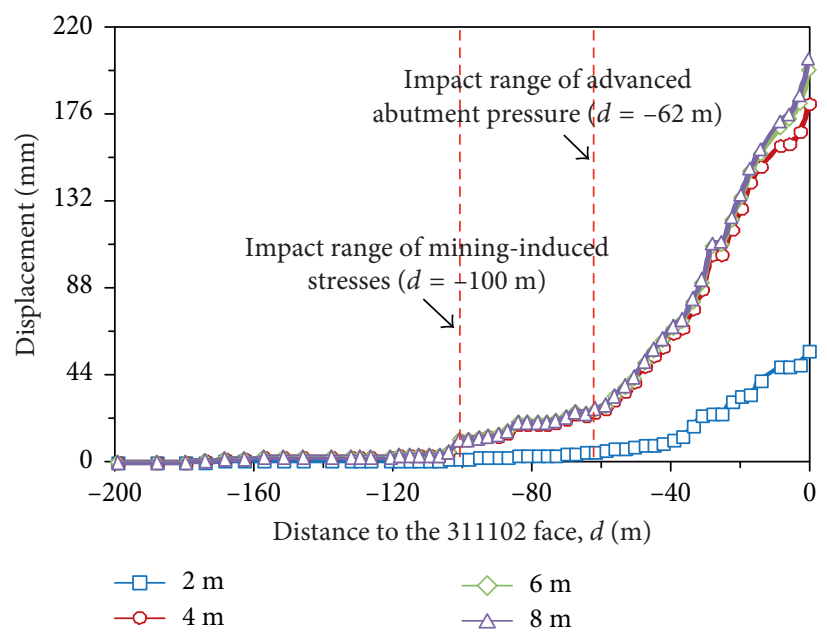

(a)

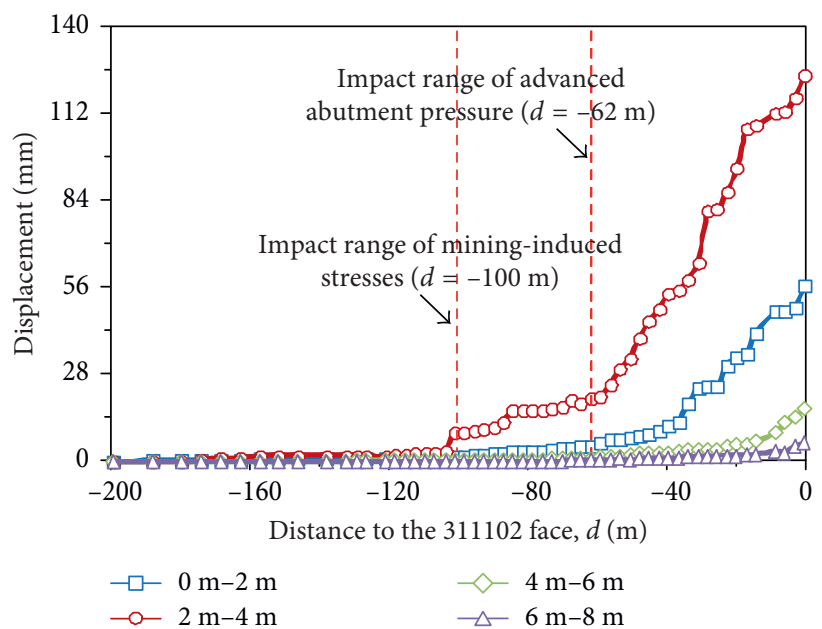

(b)

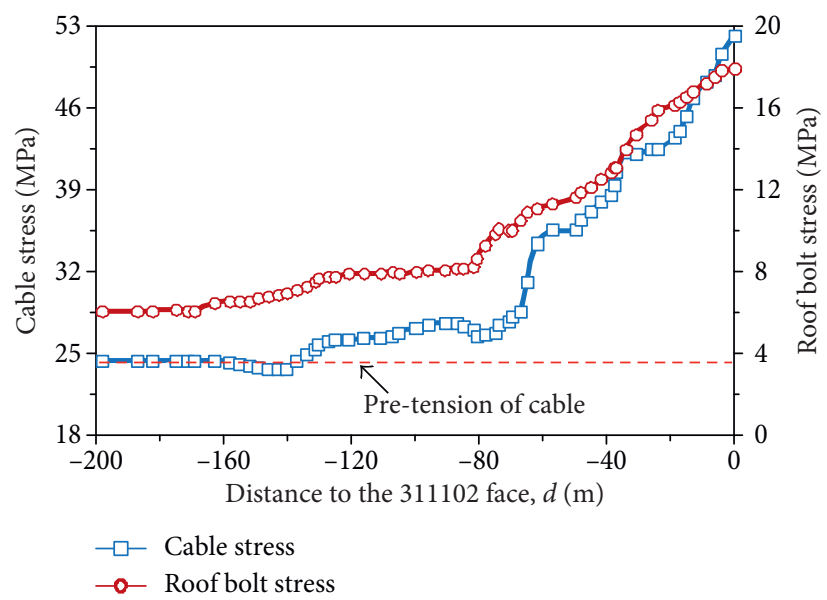

(c)

FiguRE 15: Monitoring results of roof displacement and stress on anchor cable (bolt) at section II. (a) Monitoring results of roof displacement, (b) displacements of roof stratum at different depths, and (c) monitoring results of stress on anchor cable (bolt).

layers and crushed zones in roadway roof divided the entire roof stratum into multiple thin sublayers, thus significantly reducing the stability of roof. This is also as an inducing factor for roof-fall accidents in the roadway.
Next, according to the engineering geological conditions of the working face, the occurrence mechanism of a roof-fall accident was elucidated in detail. It can be concluded that mining-induced stress and tectonic stress are the key factors 
that led to roof-fall accidents in the roadway; these are also the preconditions for the occurrence of accidents. The equipment cavern on the side of the roadway increased the span of roof stratum and thus provided advantageous conditions for the occurrence of roof-fall accidents in the roadway. In the original supporting scheme, some parameters were set as inappropriate values, the anchor bolts on roadway roof were too short, and the end-anchorage mode could not provide an effective anchorage effect. Additionally, the array pitch between anchor cables was too high, and the used poor cables could not sustain the self-weight load of the fractured stratum and easily snapped. On that basis, a novel supporting scheme was proposed: the anchor cables and bolts were more reasonably arranged, and the bolts were anchored in a full-length way. Additionally, high-strength anchor cables were used, a high pretightening force was applied on the anchor cable, and the steel bands were arranged in a crisscross pattern.

Finally, a test section with a length of $100 \mathrm{~m}$ in the ventilation roadway of number 311102 working face was selected to validate the performance of the new supporting scheme. Two monitoring sections were set in this test section to measure the mining-induced roof displacement and stress on anchor cable (bolt). During the mining, the maximum roof displacements at the two monitoring sections were $143 \mathrm{~mm}$ and $204 \mathrm{~mm}$, respectively, far smaller than the allowable deformations. The stresses on anchor cable and bolt were normal, and no anchorage-dragging and tensile failure phenomena were observed. Further, the roadway roof in the test section remained intact during the mining. According to the field monitoring results, by using the proposed new supporting scheme, the roof deformation in large-section roadways can be effectively suppressed.

\section{Data Availability}

The authors declare that all data supporting this study are available within the article.

\section{Conflicts of Interest}

The authors declare no conflicts of interest.

\section{Acknowledgments}

This work was partially funded by the State Key Research Development Program of China (2016YFC0801403), the Shandong Provincial Natural Science Foundation, China (ZR2018MEE009), and the Scientific Research Foundation of Shandong University of Science and Technology for Recruited Talents (2017RCJJ012).

\section{References}

[1] N. Zhang and C. Liu, "Arch structure effect of the coal gangue flow of the fully mechanized caving in special thick coal seam and its impact on the loss of top coal," International Journal of Mining Science and Technology, vol. 26, no. 4, pp. 593-599, 2016.
[2] H. Yan, F. He, T. Yang, L. Li, S. Zhang, and J. Zhang, "The mechanism of bedding separation in roof strata overlying a roadway within a thick coal seam: a case study from the Pingshuo Coalfield, China," Engineering Failure Analysis, vol. 62, pp. 75-92, 2016.

[3] B. Shen, A. King, and H. Guo, "Displacement, stress and seismicity in roadway roofs during mining-induced failure," International Journal of Rock Mechanics and Mining Sciences, vol. 45, no. 5, pp. 672-688, 2008.

[4] Y. L. Tan, F. H. Yu, J. G. Ning, and T. B. Zhao, "Design and construction of entry retaining wall along a gob side under hard roof stratum," International Journal of Rock Mechanics and Mining Sciences, vol. 77, pp. 115-121, 2015.

[5] X. S. Liu, J. G. Ning, Y. L. Tan, and Q. H. Gu, "Damage constitutive model based on energy dissipation for intact rock subjected to cyclic loading," International Journal of Rock Mechanics and Mining Sciences, vol. 85, pp. 27-32, 2016.

[6] J. Ning, J. Wang, J. Jiang, S. Hu, L. Jiang, and X. Liu, "Estimation of crack initiation and propagation thresholds of confined brittle coal specimens based on energy dissipation theory," Rock Mechanics and Rock Engineering, vol. 51, no. 1, pp. 119-134, 2018.

[7] G. S. Wang, W. Zhang, Y. H. Zhu, D. L. Wang, and M. P. Zhang, "Instability mechanism and supporting control technology of soft thick roof in large section coal roadway," Safety in Coal Mines, vol. 47, pp. 170-173, 2016.

[8] H. P. Kang, J. Lin, and M. J. Fan, "Investigation on support pattern of a coal mine roadway within soft rocks-a case study," International Journal of Coal Geology, vol. 140, pp. 31-40, 2015.

[9] K. S. Keim and M. S. Miller, "Case study evaluation of geological influences impacting mining conditions at a West Virginia longwall mine," International Journal of Coal Geology, vol. 41, no. 1-2, pp. 51-71, 1999.

[10] S. E. Philipson, "The control of coal bed decollement-related slickensides on roof falls in North American Late Paleozoic coal basins," International Journal of Coal Geology, vol. 53, no. 3, pp. 181-195, 2003.

[11] D. Deb, "Analysis of coal mine roof fall rate using fuzzy reasoning techniques," International Journal of Rock Mechanics and Mining Sciences, vol. 40, no. 2, pp. 251-257, 2003.

[12] H. S. B. Düzgün, "Analysis of roof fall hazards and risk assessment for Zonguldak coal basin underground mines," International Journal of Coal Geology, vol. 64, no. 1-2, pp. 104-115, 2005.

[13] D. Ma, M. Rezania, H. S. Yu, and H. B. Bai, "Variations of hydraulic properties of granular sandstones during water inrush: effect of small particle migration," Engineering $\mathrm{Ge}$ ology, vol. 217, pp. 61-70, 2017.

[14] D. Ma, X. Cai, Z. Zhou, and X. Li, "Experimental investigation on hydraulic properties of granular sandstone and mudstone mixtures," Geofluids, vol. 2018, Article ID 9216578, 13 pages, 2018.

[15] Y. L. Tan, X. S. Liu, J. G. Ning, and Y. W. Lu, "In situ investigations on failure evolution of overlying strata induced by mining multiple coal seams," Geotechnical Testing Journal, vol. 40, no. 2, pp. 1-14, 2017.

[16] T. B. Zhao, W. Y. Guo, Y. L. Tan, C. P. Lu, and C. W. Wang, "Case histories of rock bursts under complicated geological conditions," Bulletin of Engineering Geology and the Environment, pp. 1-17, 2017.

[17] T. B. Zhao, W. Y. Guo, Y. L. Tan, Y. C. Yin, L. S. Cai, and J. F. Pan, "Case studies of rock bursts under complicated 
geological conditions during multi-seam mining at a depth of 800 m," Rock Mechanics and Rock Engineering, vol. 51, no. 5, pp. 1539-1564, 2018.

[18] Z. Zhou, X. Cai, D. Ma, W. Cao, L. Chen, and J. Zhou, "Effects of water content on fracture and mechanical behavior of sandstone with a low clay mineral content," Engineering Fracture Mechanics, vol. 193, pp. 47-65, 2018.

[19] C. L. Du, J. L. Cai, and T. S. Zhang, "Mechanism of roof falls in roadways," Journal of Mining and Safety Engineering, vol. 1, pp. 111-113, 1997.

[20] M. K. Jia, "A new way of genetic classification on roof falling of bolt supporting roadway," Journal of China Coal Society, vol. 30, pp. 568-570, 2005.

[21] O. Jacobi, "The origin of roof falls in starting faces with the caving system," International Journal of Rock Mechanics and Mining Sciences, vol. 1, no. 3, pp. 313-314, 1964.

[22] Y. L. Tan, F. H. Yu, and L. Chen, "A new approach for predicting bedding separation of roof strata in underground coalmines," International Journal of Rock Mechanics and Mining Sciences, vol. 61, pp. 183-188, 2013.

[23] B. Jiang, L. Wang, Y. Lu, S. Gu, and X. Sun, "Failure mechanism analysis and support design for deep composite soft rock roadway: a case study of the Yangcheng coal mine in China," Shock and Vibration, vol. 2015, Article ID 452479, 14 pages, 2015.

[24] F. L. He and G. C. Zhang, "Deformation and failure mechanism and control technology of large section coal roadway subjected to severe mining dynamic load," Journal of Mining and Safety Engineering, vol. 33, pp. 423-430, 2016.

[25] H. Yan, F. L. He, and S. G. Wang, "Safety control and evaluation of roadway with super-large cross-section and soft-weak thick coal roof," Chinese Journal of Rock Mechanics and Engineering, vol. 33, pp. 1014-1023, 2014.

[26] X. H. Li, S. Liang, Q. L. Yao, Q. D. Qu, and L. Zhang, “Analysis on fissure-evolving law and roof-falling mechanism in roadway with mudstone roof," Journal of China Coal Society, vol. 36, no. 6, pp. 903-908, 2011.

[27] Q. L. Yao, X. H. Li, Q. D. Qu, S. J. Ren, S. Liang, and J. K. Man, "Supporting countermeasures and roof falling mechanism reacting with water in mudstone roof roadway," Journal of Mining and Safety Engineering, vol. 28, pp. 28-33, 2011.

[28] Q. Meng, L. Han, Y. Chen et al., "Influence of dynamic pressure on deep underground soft rock roadway support and its application," International Journal of Mining Science and Technology, vol. 26, no. 5, pp. 903-912, 2016.

[29] Q. Meng, L. Han, X. Yu, H. Li, S. Wen, and J. Zhang, "Numerical simulation study of the failure evolution process and failure mode of surrounding rock in deep soft rock roadways," International Journal of Mining Science and Technology, vol. 26, no. 2, pp. 209-221, 2016.

[30] W. L. Shen, J. B. Bai, W. F. Li, and X. Y. Wang, "Prediction of relative displacement for entry roof with weak plane under the effect of mining abutment stress," Tunnelling and Underground Space Technology, vol. 71, pp. 309-317, 2018.

[31] C. Mark, "Design of roof bolt system," in Proceedings of the New Technology for Coal Mine Roof Support, National Institute for Occupational Safety and Health (NIOSH), pp. 111 -131, Pittsburgh, PA, USA, 2000.

[32] M. G. Qian, P. W. Shi, and J. L. Xu, Ground Pressure and Strata Control, China University of Mining and Technology Press, Xuzhou, China, 2010.

[33] B. Shen, "Coal mine roadway stability in soft rock: a case study," Rock Mechanics and Rock Engineering, vol. 47, no. 6, pp. 2225-2238, 2014.
[34] T. K. Lu and Y. H. Dai, "Performance of fully encapsulated resin rock bolt in laminated roof strata of longwall roadway," Chinese Journal of Rock Mechanics and Engineering, vol. 29, pp. 3329-3335, 2010.

[35] J. Stankus and S. Peng, "A new concept for roof support," Coal Age, vol. 9, pp. 2-6, 1996.

[36] S. Peng, "Roof bolting adds stability to weak strata," Coal Age, vol. 11, pp. 32-38, 1998. 


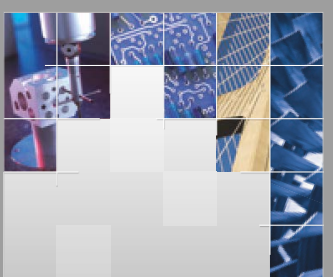

\section{Enfincering}
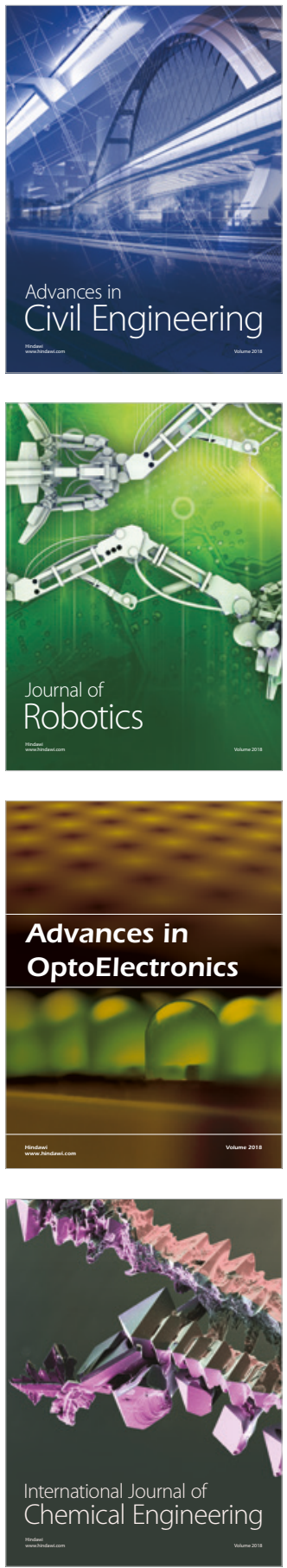

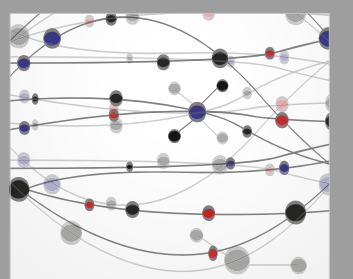

\section{Rotating \\ Machinery}

The Scientific World Journal

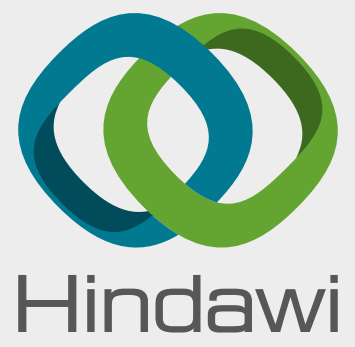

Submit your manuscripts at

www.hindawi.com
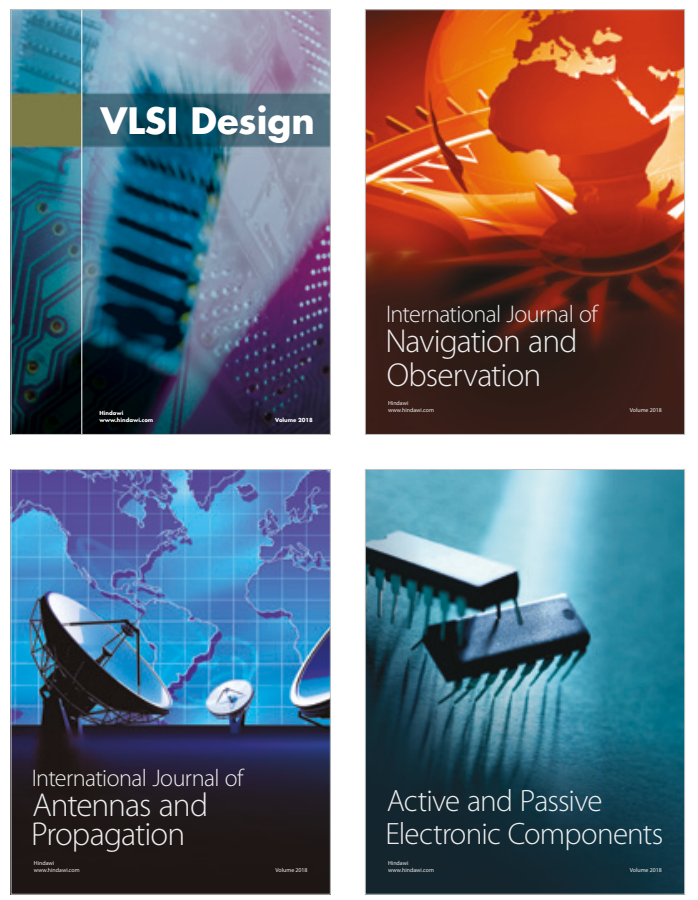
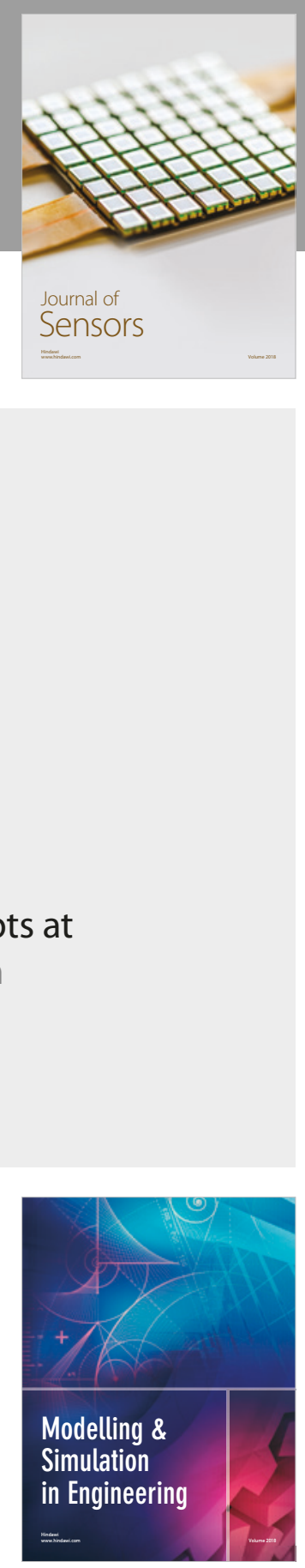

\section{Advances \\ Multimedia}
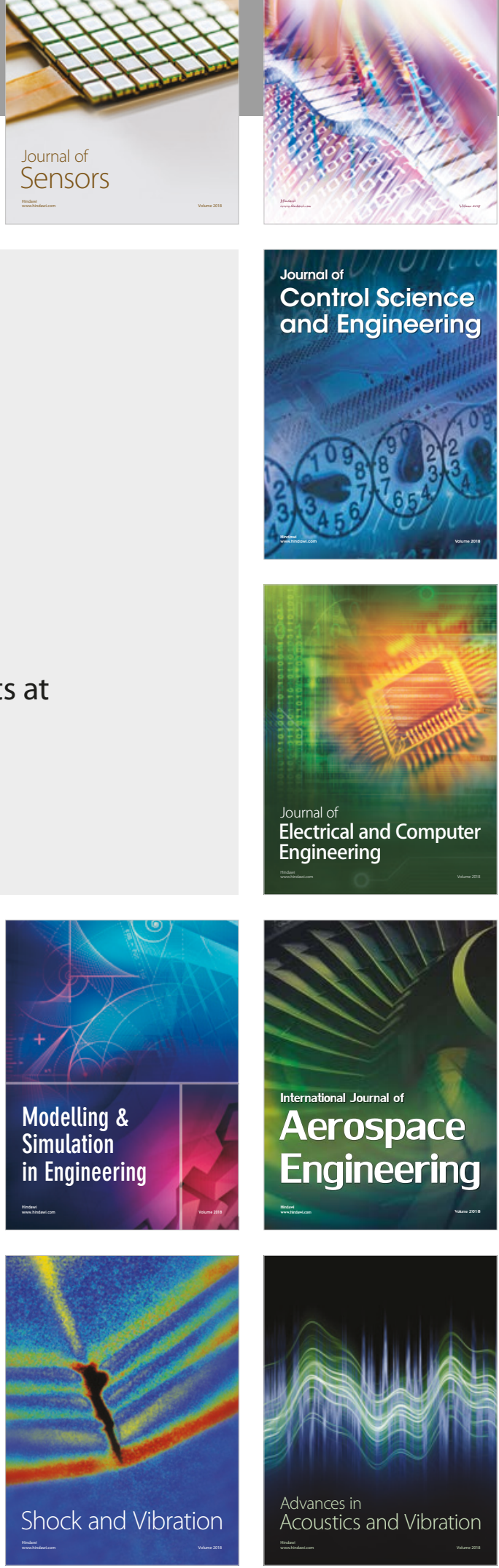